\title{
Selective inhibitors of phosphoinositide 3-kinase delta: modulators of B-cell function with potential for treating autoimmune inflammatory diseases and B-cell malignancies
}

\author{
Kamal D. Puri ${ }^{1 *+}$ and Michael R. Gold ${ }^{2 *+}$ \\ Gilead Sciences, Inc., Seattle, WA, USA \\ ${ }^{2}$ Department of Microbiology and Immunology, ${ }^{3}$ and CELL Research Groups, Life Sciences Institute, University of British Columbia, Vancouver, BC, Canada
}

\section{Edited by:}

Klaus Okkenhaug, Babraham

Institute, UK

Reviewed by:

Aaron J. Marshall, University of

Manitoba, Canada

David A. Fruman, University of

California, Irvine, USA

*Correspondence:

Kamal D. Puri, Gilead Sciences, Inc., 199 East Blaine Street, Seattle, WA 98102, USA.

e-mail: kamal.puri@gilead.com

Michael R. Gold, Department of

Microbiology and Immunology, University of British Columbia, 2350 Health Sciences Mall,

Vancouver, BC V6T 1Z3, Canada. e-mail:mgold@interchange.ubc.ca

${ }^{+}$These authors contributed equally to this work.
The delta isoform of the p110 catalytic subunit (p1108) of phosphoinositide 3-kinase is expressed primarily in hematopoietic cells and plays an essential role in B-cell development and function. Studies employing mice lacking a functional p1108 protein, as well as the use of highly-selective chemical inhibitors of p1108, have revealed that signaling via p110 $\delta$-containing PI3K complexes (PI3K $\delta$ ) is critical for B-cell survival, migration, and activation, functioning downstream of key receptors on B cells including the B-cell antigen receptor, chemokine receptors, pro-survival receptors such as BAFF- $R$ and the IL-4 receptor, and co-stimulatory receptors such as CD40 and Toll-like receptors (TLRs). Similarly, this PI3K isoform plays a key role in the survival, proliferation, and dissemination of B-cell lymphomas. Herein we summarize studies showing that these processes can be inhibited in vitro and in vivo by small molecule inhibitors of p110 enzymatic activity, and that these p1108 inhibitors have shown efficacy in clinical trials for the treatment of several types of B-cell malignancies including chronic lymphocytic leukemia (CLL) and non-Hodgkin lymphoma (NHL). PI3K $\delta$ also plays a critical role in the activation, proliferation, and tissue homing of self-reactive $B$ cells that contribute to autoimmune diseases, in particular innate-like B-cell populations such as marginal zone (MZ) B cells and B-1 cells that have been strongly linked to autoimmunity. We discuss the potential utility of p1108 inhibitors, either alone or in combination with B-cell depletion, for treating autoimmune diseases such as lupus, rheumatoid arthritis, and type 1 diabetes. Because PI3K $\delta$ plays a major role in both B-cell-mediated autoimmune inflammation and B-cell malignancies, $\mathrm{P} \mid 3 \mathrm{~K} \delta$ inhibitors may represent a promising therapeutic approach for treating these diseases.

Keywords: phosphoinositide 3-kinase, p110delta, autoimmunity, GS-1101, CAL-101, IC87114, non-Hodgkin lymphoma, leukemia

\section{THE ROLE OF PI3K SIGNALING IN B-CELL}

\section{DEVELOPMENT AND ACTIVATION}

B cells play a critical role in immune system function and dysfunction (e.g., autoimmunity) by producing antibodies and by acting as antigen-presenting cells (APCs) for T cells. Signaling via phosphoinositide 3-kinase (PI3K) controls many essential B cell functions and is therefore a promising target for preventing aberrant B cell activation. The class I PI3K enzymes consist of a regulatory subunit that allows receptors to recruit PI3K to the plasma membrane, and a catalytic subunit, which can then phosphorylate phosphoinositide lipids on the $3^{\prime}$ position of their inositol head group. The lipid second messengers generated by PI3K, primarily phosphatidylinositol 3,4,5-trisphosphate ( $\left.\mathrm{PIP}_{3}\right)$, can recruit cytosolic signaling enzymes that contain pleckstrin homology (PH) domains to the plasma membrane (Lemmon, 2008). The resulting formation of protein complexes facilitates the activation of these signaling enzymes and brings them in close proximity to their substrates. The PI3K "effectors" that are recruited to the plasma membrane and activated in this manner include signaling enzymes that control cell survival, activation growth, proliferation, and differentiation, as well as cell motility, cell adhesion, and specialized processes such as phagocytosis (Okkenhaug and Vanhaesebroeck, 2003; Fruman, 2004). The structure, enzymatic activity, and functions of the class I PI3Ks have been described in detail in many excellent reviews (Okkenhaug and Fruman, 2010; Vanhaesebroeck et al., 2010; So and Fruman, 2012).

PI3K signaling is important for B-cell development (Fruman et al., 1999; Suzuki et al., 1999; Clayton et al., 2002; Okkenhaug et al., 2002) due its role in mediating the survival and differentiation signals that are initiated by the pre-B-cell receptor (Ramadani et al., 2010). In mature B cells, PI3K transduces signals from a wide variety of receptors that control nearly all aspects of B-cell function. The survival of naïve B cells depends 
on constitutive low-level antigen-independent activation of PI3K by the B-cell receptor (BCR) (Srinivasan et al., 2009) and by the receptor for the cytokine B-cell activating factor (BAFF) (Henley et al., 2008). These survival signals may be mediated, at least in part, by the Akt protein kinase, a major downstream target of PI3K signaling. Akt activates multiple pro-survival pathways while inhibiting pro-apoptotic pathways.

The detection of foreign antigens by circulating B cells depends on the ability of B cells to traffic into lymphoid organs and migrate into the lymphoid follicles, where antigens are captured and retained via multiple mechanisms (Batista and Harwood, 2009). The in vivo trafficking of B cells is directed by chemokines such as CXCL13 and CCL21 as well as the lipid chemoattractant sphingosine 1-phosphate (S1P) (Stein and Nombela-Arrieta, 2005). The $G$ protein-coupled receptors that bind chemoattractants activate PI3K, and this is critical for B cells to migrate towards these stimuli. Once B cells encounter a foreign antigen, which in the case of an infection will occur in the presence of microbially-derived ligands for Toll-like receptors (TLRs), PI3K signaling is essential for B-cell activation and proliferation as well as the subsequent differentiation of B cells into antibodyproducing cells and the survival of memory B cells. As described in detail elsewhere (Fruman, 2004), PI3K plays a central role in the activation of many BCR signaling pathways. In particular, $\mathrm{PIP}_{3}$-dependent activation of Bruton's tyrosine kinase (Btk) is crucial for the activation of phospholipase C- $\gamma$, an enzyme that splits phosphatidylinositol 4,5-bisphosphate $\left(\mathrm{PIP}_{2}\right)$ into inositol 1,4,5-trisphosphate $\left(\mathrm{IP}_{3}\right)$ and diacylglycerol, second messengers that lead to increases in intracellular $\mathrm{Ca}^{2+}$, activation of multiple protein kinase $\mathrm{C}$ isoforms, activation of the NF- $\mathrm{B}$ and NF-AT transcription factors, and activation of the Ras and Rap1 GTPases, the latter of which is a master regulator of cytoskeletal reorganization and integrin-mediated adhesion. B-cell activation also requires critical input from co-stimulatory receptors such as CD40 and the IL-4 receptor, which transduce signals from helper T cells, as well as TLRs, which are now thought of as a third signal for B-cell activation. CD40, the IL-4 receptor, and the main TLRs expressed by B cells, TLR4 and TLR9, all signal via PI3K (Figure 1). Not only does PI3K signaling act downstream of multiple receptors that drive different steps in the B-cell activation process (Donahue and Fruman, 2004), it is also important for B cells to bind to T cells so that they can act as APCs and elicit T cell help in the form of CD40 ligand and IL-4 (Al-Alwan et al., 2007).

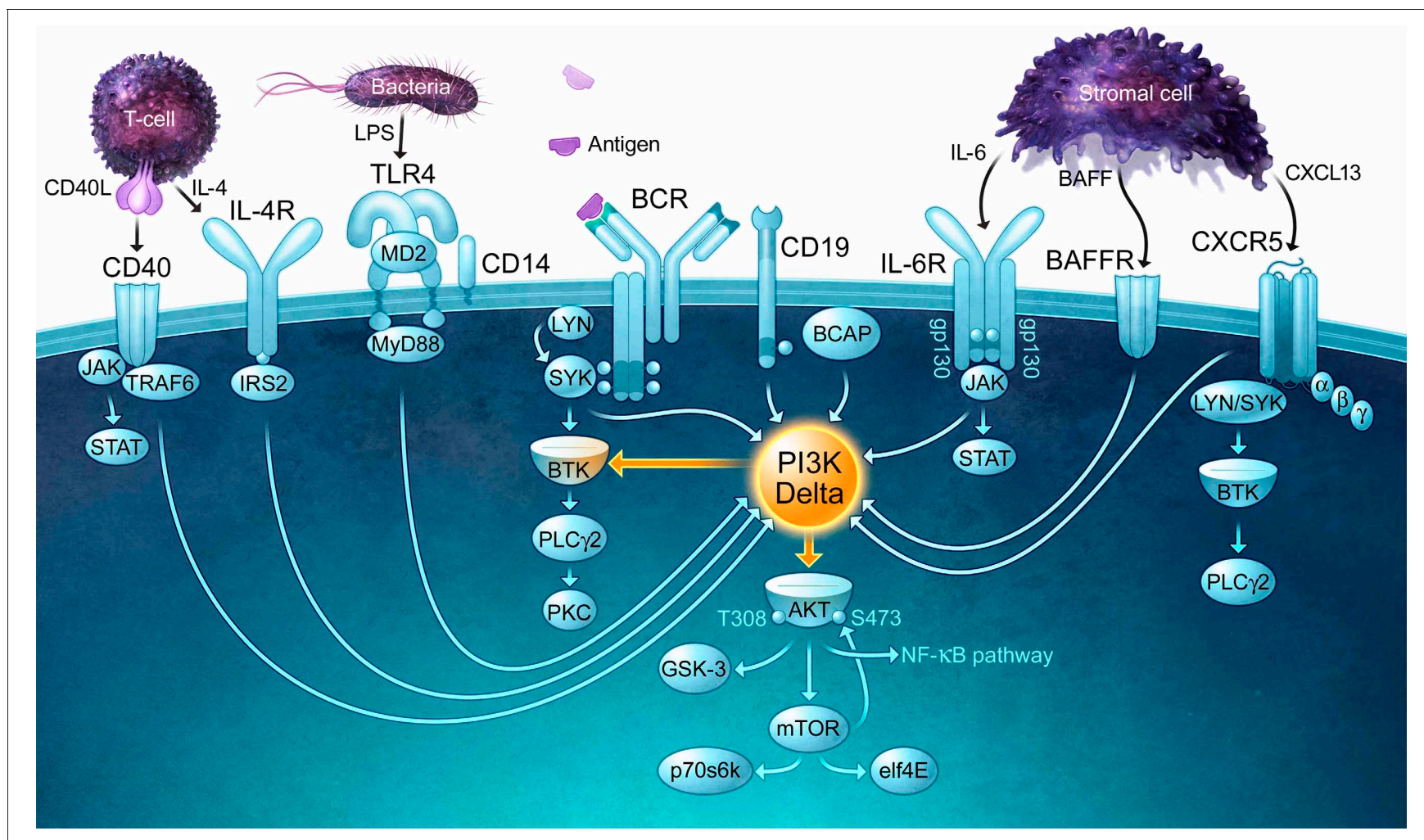

FIGURE 1 | PI3K $\delta$ is a central signaling enzyme that mediates the effects of multiple receptors on B cells. PI3K $\delta$ signaling is important for B-cell survival, migration, and activation, functioning downstream of the B-cell antigen receptor (BCR) and its co-receptor CD19, chemokine receptors (CXCR5), and activating/co-stimulatory receptors such as CD40 and Toll-like receptors (TLRs). Cytokines derived from lymphoid stromal cells (BAFF, IL-6) and $T$ cells (IL-4) that are essential for the expansion and survival of B cells also require $\mathrm{PI} 3 \mathrm{~K} \delta$ for their actions and bind receptors that activate $\mathrm{PI} 3 \mathrm{~K} \delta$. The receptors depicted in this figure use a variety of kinases and adaptor proteins to recruit $\mathrm{PI} 3 \mathrm{~K} \delta$ to the plasma membrane, where it can produce the lipid second messenger $\mathrm{PIP}_{3}$. By binding to $\mathrm{PH}$ domain-containing proteins, $\mathrm{PIP}_{3}$ promotes the activation of multiple signaling enzymes including PLC $\gamma 2$ and Akt, both of which control key signaling networks. Note that the connecting arrows may represent multiple intermediate signaling reactions. 


\section{ISOFORM-SPECIFIC FUNCTIONS: A CRITICAL ROLE FOR PI3K $\delta$ IN B CELLS}

There are four isoforms of class I PI3K catalytic subunits: $\mathrm{p} 110 \alpha$, $\mathrm{p} 110 \beta, \mathrm{p} 110 \gamma$, and $\mathrm{p} 110 \delta$. Although these enzymes appear to have identical substrate specificity, they clearly have distinct functions in vivo, as revealed by the generation of mouse strains in which the genes encoding these different catalytic subunits have either been disrupted or replaced by a catalytically inactive version (Rommel et al., 2007; Vanhaesebroeck et al., 2010; So and Fruman, 2012). This could be explained in part by differential expression or abundance of the various isoforms in specific tissues. In particular, p $110 \gamma$ and p $110 \delta$ are expressed primarily in hematopoietic cells and have important roles in the functions of both innate and adaptive immune cells (Rommel et al., 2007). It is more difficult to explain how different PI3K isoforms can play distinct roles within the same cell. Proposed models usually invoke preferential recruitment of specific PI3K isoforms by different receptors or to different membrane domains, which results in the formation of distinct signaling complexes. This would presumably depend on unique structural features of the different catalytic subunits mediating specific interactions.

An intriguing finding is that $\mathrm{p} 110 \alpha$ is important for the tonic antigen-independent survival signals generated by the pre-BCR and BCR whereas $\mathrm{p} 110 \delta$ (but not $\mathrm{p} 110 \alpha$ ) is required for antigendependent B-cell activation driven by the BCR (Ramadani et al., 2010). These distinct roles of $\mathrm{p} 110 \alpha$ and $\mathrm{p} 110 \delta$ in homeostatic versus antigen-induced BCR signaling could reflect different mechanisms by which PI3K complexes are recruited to the plasma membrane in resting versus activated B cells. The TC21 GTPase can directly bridge PI3K catalytic subunits to the nonphosphorylated BCR immunoreceptor tyrosine-based activation motifs (ITAMs) in resting B cells, thereby promoting homeostatic PI3K signaling (Delgado et al., 2009). In contrast, antigeninduced BCR clustering, and the resulting tyrosine kinase activation and ITAM phosphorylation, could abrogate the binding of TC21 to the BCR and instead promote SH2-mediated binding of PI3K to BCAP and CD19, scaffolding proteins that are tyrosine phosphorylated after BCR engagement. This model would require that TC21 preferentially recruit p110 $\alpha$-containing PI3K complexes whereas BCAP and CD19 preferentially recruit p110 $\delta$ containing PI3K complexes. The finding that TC21 recruits $\mathrm{p} 110 \delta$ to the BCR in resting B cells (Delgado et al., 2009) does not support this idea. However, this group did not assess whether p110 $\alpha$ was also recruited to the BCR by TC21. Thus, the basis for the differential role of $\mathrm{p} 110 \alpha$ and $\mathrm{p} 110 \delta$ in homeostatic versus antigen-initiated BCR signaling remains to be determined.

Although B cells express all four isoforms of the class I PI3K p110 catalytic subunit (Bilancio et al., 2006), the p110 isoform has an essential and non-redundant role in many aspects of $\mathrm{B}$ cell development and activation. In mice lacking a functional p110 $\delta$ protein, fewer mature circulating B cells (i.e., follicular or B-2-B cells) are generated and the B cells that do develop exhibit impaired chemokine-induced migration, BCR signaling, and BCR-induced proliferation, which correlates with reduced differentiation into antibody-producing cells and reduced serum Ig levels both before and after immunization (Clayton et al., 2002; Jou et al., 2002; Okkenhaug et al., 2002; Reif et al., 2004). This is in contrast to knockout mice that lack the leukocyte-specific p110 $\gamma$ catalytic subunit, which is often linked to signaling by $\mathrm{G}$ proteincoupled receptors. Even though p110 $\gamma$ is normally expressed in $\mathrm{B}$ cells, mice lacking $\mathrm{p} 110 \gamma$ have no apparent defects in B-cell development or function (Sasaki et al., 2000). PI3K $\delta$ also appears to have a unique role in B-cell development and function in humans. Several genetic polymorphisms in the p110 gene have been identified and a patient with a primary B-cell immunodeficiency was found to have a missense mutation that resulted in an aspartic acid to lysine replacement within the catalytic domain of p110 (Jou et al., 2006).

Highly selective small molecule inhibitors of p110 such as IC87114 (Sadhu et al., 2003a,b) and GS-1101, which is also known as CAL-101 (Lannutti et al., 2011), allow inhibition of this PI3K isoform both in vivo and in cells derived from normal animals. The inhibitory effects of IC87114 phenocopy the effects of disrupting the $110 \delta$ gene or replacing it with a mutant version that encodes a catalytically inactive form of p1108 (Okkenhaug et al., 2002; Bilancio et al., 2006), supporting the idea that this drug is highly selective for p $110 \delta$ and can therefore be used as a probe for p110 function. The use of IC87114 has provided significant insights into the role of p1108 in mature B cells. In vitro, treating murine splenic B cells with IC87114 significantly reduces IL-4-dependent B-cell survival, CXCL13-induced B-cell migration, the ability of $\mathrm{B}$ cells to present antigens to $\mathrm{T}$ cells, TLR-induced cytokine production, and both BCR- and TLRmediated B-cell activation, proliferation, differentiation, and antibody secretion (Bilancio et al., 2006; Dil and Marshall, 2009; Durand et al., 2009). IC87114 is also highly active in vivo and we have shown that it can reduce antigen-specific antibody responses in rodents (Durand et al., 2009).

\section{THE ROLE OF PI3K $\delta$ IN THE DEVELOPMENT, LOCALIZATION, AND FUNCTION OF INNATE-LIKE B CELLS}

The majority of B cells are conventional circulating B-2 cells. However the marginal zone (MZ) B cells and B-1 subsets also play important roles in host defense (Pillai et al., 2005; Baumgarth, 2011). B-1 cells are found in the peritoneal cavity and the spleen, whereas MZ B cells reside near the marginal sinus of the spleen where they are positioned to rapidly detect blood-borne microbial infections. The Ig repertoires of B-1 and MZ B cells are skewed toward the recognition of both microbial antigens and self-antigens. So-called natural antibodies that are produced by these B-cell subsets in the absence of any antigen stimulation (as well as in germ-free mice) recognize cross-reactive epitopes on Gram-positive bacteria, viruses, apoptotic cells, and oxidized lowdensity lipoproteins (Ochsenbein et al., 1999; Zhang and Carroll, 2007; Binder et al., 2008). This provides protection against infection and also prevents inflammation by clearing oxidized lipids, oxidized proteins, and apoptotic cells (Binder et al., 2008; Chou et al., 2008; Baumgarth, 2011). In addition, exposure to TLR ligands leads to a rapid increase in antibody production by B-1 and MZ B cells. Hence, these B-cell subsets have been termed "innatelike" B cells because of their constitutive production of protective antibodies, their ability to mount rapid responses to infection, and their localization to specific sites where they act as sentinels of infection. 
A striking observation is that mice in which the gene encoding the p110 $\delta$ subunit has been disrupted or replaced with a catalytically inactive version have very few B-1 or MZ B cells (Clayton et al., 2002; Okkenhaug et al., 2002). The reasons why the development of these B-cell subsets is strongly dependent on p110 are not fully understood although PI3K-dependent Akt activation appears to be more important for the development of B-1 and MZ B cells than conventional B cells. Irradiated mice reconstituted with hematopoietic progenitors that lack both the Akt1 and Akt2 isoforms develop normal numbers of circulating B-2 cells but lack MZ B cells and have greatly reduced numbers of B-1 cells (Calamito et al., 2010). The self-reactive nature of B-1 and MZ B cells has led to the idea that B-cell progenitors are directed into these lineages by weak BCR signals initiated by the binding of self-antigens, which could induce PI3K signaling. Where and when this self-antigen encounter occurs is not clear. B-1 cells are thought to arise from a unique population of committed B-1 progenitor cells that retain self-renewal capacity (Montecino-Rodriguez et al., 2006). MZ B cells arise from transitional cells in the spleen that can give rise to either conventional "follicular" B-2 cells or to MZ cells, a cell fate decision in which Notch signaling promotes the MZ B cell fate (Pillai and Cariappa, 2009). The role of PI3K $\delta$ signaling in these cell fate decisions is not known, although it has been proposed that FOXO transcription factors, which are inhibited by PI3K-Akt signaling, may oppose the effects of Notch signaling (Chen et al., 2010).

Because B-1 and MZ B cells are nearly absent in mice lacking a functional $\mathrm{p} 110 \delta$ protein, we have used the $\mathrm{p} 110 \delta$-selective inhibitor IC87114 to assess the role of this PI3K isoform in B1 and MZ B cells that had developed in normal wild-type mice. These studies revealed a number of critical roles for p110 $\delta$ activity in innate-like B cells (Durand et al., 2009). The localization of innate-like B cells is critical for their ability to mount rapid T cellindependent antibody responses against pathogens. For MZ B cells, their location near the marginal sinus of the spleen positions them to rapidly detect blood-borne pathogens. The retention of $\mathrm{MZ} \mathrm{B}$ cells in this region surrounding the B-cell follicles is maintained by integrin-mediated adhesion and by opposing chemoattractant gradients established by the chemokine CXCL13, which is produced by follicular dendritic cells within the B-cell follicle and the lipid chemoattractant S1P, which is present at high concentrations in the blood (Cinamon et al., 2004). In response to TLR ligands as an indicator of infection or tissue damage, MZ B cells can move into the B-cell follicles and may eventually exit the spleen and migrate to other tissues in response to CXCL13 (Marino et al., 2008; Rubtsov et al., 2008). Similarly, the mobilization of peritoneal B-1 cells to mucosal sites of infection is stimulated by TLR ligands and depends on a robust migratory response to the chemokine CXCL13 (Ha et al., 2006). Our in vitro studies showed that $\mathrm{p} 110 \delta$ activity is important for B-1 cells to migrate toward CXCL13 and for MZ B cells to exhibit chemotactic responses to both CXCL13 and S1P (Durand et al., 2009). In addition, CXCL13-stimulated adhesion of MZ $\mathrm{B}$ cells to the integrin ligand ICAM-1 was reduced to below basal level when these cells were treated with IC87114 (Durand et al., 2009). Consistent with the finding that in vitro treatment of MZ B cells with IC87114 inhibited both chemoattractantinduced migration and adhesion, oral administration of IC87114 to mice dramatically reduced the number of MZ B cells surrounding the B-cell follicles of the spleen, similar to what is seen in mice lacking a functional p110 protein (Durand et al., 2009).

What are the molecular mechanisms by which $\mathrm{PI} 3 \mathrm{~K} \delta$ signaling promotes the cell motility and cell adhesion that control the localization of MZ B cells? CXCL13- and S1P-induced B-cell migration and adhesion are strongly dependent on activation of the Rap1 GTPase (Durand et al., 2006), a master regulator of cytoskeletal organization, cell polarity, cell motility, and integrin activation (Bos, 2005). Our finding that p110 $\delta$ activity is required for CXCL13 and S1P to activate Rap1 in B cells (Durand et al., 2009), combined with the observation that Raplb-deficient mice have greatly reduced numbers of $\mathrm{MZ}$ B cells (Chen et al., 2008), suggests that p110 $\delta$-dependent activation of Raplb is essential for the in vivo localization of $\mathrm{MZ}$ $B$ cells.

$\mathrm{PI} 3 \mathrm{~K} \delta$ signaling also plays an essential role in the activation of innate-like B cells. Treating murine splenic MZ B cells or B-1 cells with either IC87114 or the pan-PI3K inhibitor LY294002 cause nearly complete inhibition of Akt phosphorylation that is stimulated by CXCL13, by the TLR9 ligand CpG DNA, or anti-Ig antibodies that cluster the BCR. IC87114 also inhibits S1P-induced Akt phosphorylation in MZ B cells (neither B-1 nor B-2 cells respond well to S1P). These findings suggest that p1108 is the main PI3K isoform linking the BCR, TLR9, and the receptors for CXCL13 and S1P to activation of the Akt prosurvival kinase in innate-like B cells. This is somewhat surprising with regard to chemoattractant signaling since $G$ protein-coupled receptors such as those that bind CXCL13 and S1P are often coupled to PI3K $\gamma$. PI3K $\gamma$ is expressed in B cells (Bilancio et al., 2006), although this analysis has not been carried out on isolated B-1 or MZ B cell populations. However, mice lacking p110 $\gamma$ have no apparent defects in B-cell development or function (Sasaki et al., 2000), suggesting that p110 substitutes for p110 $\gamma$ in linking G protein-coupled receptors to the PI3K/Akt pathway in B cells. Befitting their role as sentinels that provide early detection and protection from infection, innate-like B cells are most frequently activated in a polyclonal manner by TLR ligands. The ability of the TLR ligands lipopolysaccharide (LPS) and $\mathrm{CpG}$ DNA to induce the proliferation of B-1 and MZ B cells and to increase antibody secretion by purified splenic MZ cells or peritoneal B-1 cells is substantially reduced in the presence of the p1108 inhibitor IC87114 (Durand et al., 2009). Recent work has suggested the TLRs may activate p110 $\gamma$ in myeloid cells (Schmid et al., 2011) but its contribution to TLR-induced activation of innate-like B cells has not been assessed. Nevertheless, it is clear that p $110 \delta$ activity is critical for the activation of innate-like B cell populations by chemokines, antigens, and TLR ligands.

Taken together, these data suggest that p110 inhibitors such as IC87114 may be useful for inhibiting the in vivo trafficking, localization, and activation of MZ B cells and B-1 cells, innate-like $\mathrm{B}$-cell populations that have been strongly implicated in a variety of autoimmune diseases. 


\section{PI3KS AS A TARGET FOR TREATING B CELL-MEDIATED AUTOIMMUNE DISEASES}

Autoimmune inflammatory diseases such as rheumatoid arthritis, systemic lupus erythematosus (SLE), and type 1 diabetes affect millions of people worldwide. The aging population, especially in the developed world, as well as complex environmental factors, has contributed to a significant increase in the number of patients requiring treatment. Although there have been dramatic advances in the development of biological treatments in the form of antibodies and recombinant proteins, not all patients experience effective disease management. Hence there continues to be a need for new treatment approaches that provide effective long-term protection from disease progression with minimal side effects, simple delivery, and reasonable cost.

\section{THE ROLE OF B CELLS IN CHRONIC AUTOIMMUNE INFLAMMATORY DISEASES}

$B$ cells play a major role in a number of autoimmune diseases via their production of autoantibodies, their ability to act as APCs that present self-antigens to autoreactive $\mathrm{T}$ cells, and their production of pro-inflammatory cytokines (Murakami and Honjo, 1997; Fields and Erikson, 2003; Martin and Chan, 2006; Shlomchik, 2008; Yanaba et al., 2008). The role of B cells in the pathogenesis of rheumatoid arthritis, type 1 diabetes, multiple sclerosis, SLE, and several other autoimmune inflammatory diseases has been described in detail elsewhere (Yanaba et al., 2008).

Aberrant B-cell activation and polyclonal antibody production can occur when there are defects in negative regulators of BCR signaling such as the Shp1 tyrosine phosphatase. In mice, the loss of Shpl only in B cells is sufficient to cause an SLE-like disease (Pao et al., 2007). Viral and bacterial infections may also trigger autoimmunity by causing polyclonal activation of $\mathrm{B}$ cells via TLRs. In contrast to polyclonal B-cell activation, the loss of B-cell tolerance due either to intrinsic defects or to aberrant T-cell activation can result in the production of characteristic autoantibodies, for example the "rheumatoid factor" anti-IgG antibodies that are associated with rheumatoid arthritis. Autoantibodies can greatly amplify inflammatory responses and thereby play an important role in promoting tissue damage. Immune complexes containing IgM or IgG autoantibodies can initiate complementmediated inflammation and can activate inflammatory cells by binding to Fc receptors. The formation of large immune complexes can also cause blockages that lead to glomerulonephritis or thrombosis (Lipsky, 2001). Finally, autoantibodies that bind to host cells may promote antibody-dependent cellular cytotoxicity carried out by NK cells or macrophages.

More recent data have shown that B cells can also initiate and amplify autoimmune disease via their ability to present antigens to $\mathrm{T}$ cells. This has been demonstrated convincingly in the nonobese diabetic (NOD) mouse model of spontaneous autoimmune type 1 diabetes. NOD mice that lack B cells (NOD $\mu \mathrm{MT}$ mice) do not develop diabetes (Serreze et al., 1996). However, NOD mice in which $\mathrm{B}$ cells are present but cannot secrete antibodies develop diabetes to the same extent as wild-type NOD mice (Wong et al., 2004). This suggests that the major role for B cells in autoimmune diabetes is as APCs. Consistent with this conclusion,
$\mathrm{B}$ cells are required for the proliferation of diabetogenic T cells in NOD mice (Katz et al., 1993; Serreze et al., 1996; Falcone et al., 1998; Noorchashm et al., 1999a; Tian et al., 2006; Marino and Grey, 2008) and for the activation and survival of $\mathrm{CD}^{+} \mathrm{T}$ cells that infiltrate the pancreas and attack the insulin-producing beta cells (Brodie et al., 2008). The hyperactivated B cells present in autoimmune animals and patients are highly effective APCs because they express elevated levels of MHC proteins and the T cell co-stimulatory molecules CD80 and CD86 on their surface.

Cytokine production by $\mathrm{B}$ cells may also contribute to the progressive amplification of autoimmune processes. Activated B cells can produce pro-inflammatory cytokines such as IL-6 (Shlomchik, 2008; Yanaba et al., 2008). Moreover, in chronic inflammatory autoimmune diseases such as rheumatoid arthritis, lymphotoxin- $\beta$ produced by $B$ cells promotes the formation of ectopic GCs within the inflamed tissue (Takemura et al., 2001; Bugatti et al., 2007). Activated B cells that enter these germinal centers undergo clonal expansion, somatic hypermutation, and affinity maturation, leading to increased production of higher affinity self-reactive antibodies (Kim and Berek, 2000).

\section{THE ROLE OF INNATE-LIKE B CELLS IN AUTOIMMUNITY}

In a number of mouse models of autoimmune inflammatory diseases such as rheumatoid arthritis and SLE, disease progression is strongly associated with an expansion of B-1 and MZ B cell populations and a corresponding increase in the production of self-reactive antibodies that may contribute to the autoimmune pathology (Batten et al., 2000; Duan and Morel, 2006; Ishida et al., 2006; Bugatti et al., 2007; Pao et al., 2007; Marino et al., 2008).

The role of innate-like $\mathrm{B}$ cells in autoimmunity has been characterized extensively in mouse models of autoimmune diabetes that closely resemble autoimmune type 1 diabetes in humans. In type 1 diabetes, $\mathrm{T}$ cells specific for pancreatic beta cells become activated and infiltrate the islets of Langerhans. $\mathrm{CD}^{+}$cytotoxic T cells directly kill beta cells while pathogenic CD4 ${ }^{+} \mathrm{T}_{\mathrm{H}} 1$ cells recruit macrophages that produce inflammatory mediators such as IL- $1 \beta$, TNF- $\alpha$, and nitric oxide, which combine to cause beta cell dysfunction and death. The net result is progressive destruction of the beta cells, leading to insulin deficiency and hyperglycemia. At least in the NOD mouse model of spontaneous autoimmune diabetes, innate-like B cells appear to play an important role in disease progression. NOD mice have increased numbers of MZ B cells (Marino et al., 2008), a phenotype that maps to the Idd9/11 diabetes susceptibility locus (Rolf et al., 2005). Prior to the onset of diabetes in NOD mice, activated MZ B cells accumulate in the pancreatic lymph node (Marino et al., 2008), the main site of activation of diabetogenic T cells. MZ B cells are efficient APCs (Attanavanich and Kearney, 2004), express $\mathrm{T}$ cell co-stimulatory molecules when activated (Oliver et al., 1999; Wither et al., 2000; Marino et al., 2008), and can effectively present beta cell antigens to self-reactive $\mathrm{T}$ cells from NOD mice and induce their proliferation (Marino et al., 2008). Consistent with a role for MZ B cells in the development of autoimmune diabetes, the somewhat selective depletion of $\mathrm{MZ} \mathrm{B}$ cells with antibodies to CD21/CD35 reduces the disease incidence in a mouse model (Noorchashm et al., 1999b). B-1 cells may also promote the autoimmune destruction of islet cells. B-1 cells are 
found primarily in the peritoneal cavity but have been shown to traffic to the pancreas prior to the onset of type 1 diabetes in a mouse model of the disease (Ryan et al., 2010). In the pancreas, B- 1 cells promote the infiltration of diabetogenic $T$ cells by inducing the pancreatic vasculature to express VCAM-1 (Ryan et al., 2010), an integrin ligand that supports T cell extravasation. Thus the combined actions of MZ B cells and B-1 cells may be a key factor in the activation of diabetogenic $\mathrm{T}$ cells and their ability to infiltrate the pancreas, where they orchestrate the destruction of insulin-producing islet cells.

The role of innate-like B cells in autoimmune diseases in humans has yet to be fully explored because the equivalent cell populations have been more difficult to identify. A CD $27^{+}$human $\mathrm{B}$-cell subset has been likened to murine MZ B cells in that these cells can generate rapid T-independent antibody responses against the carbohydrate capsules of pathogenic Gram-positive bacteria. However, unlike murine MZ B cells that are localized mainly to the spleen and express an "innate" germ-line encoded Ig repertoire, $\mathrm{CD} 27^{+}$human B cells circulate and their Ig repertoire appears to have undergone antigen-independent somatic hypermutation that may be similar to the way that the B cell Ig repertoire is generated in sheep and other species (Weill et al., 2009). These cells may therefore represent an innate-like B-cell population that does not have an equivalent in the mouse. It is not known whether their Ig repertoire is skewed towards selfreactivity or if they contribute to autoimmunity. In contrast, two distinct subpopulations of human B-1 cells can be distinguished by surface markers and transcriptome profile and a recent report has shown that the $\mathrm{CD} 11 \mathrm{~b}^{+}$human $\mathrm{B}-1$ subset can activate $\mathrm{T}$ cells and is dramatically increased in SLE patients (Griffin and Rothstein, 2011). The identification of these subsets will undoubtedly lead to further studies of their functions and their potential roles in autoimmunity.

\section{TARGETING B CELLS TO TREAT AUTOIMMUNITY}

The multiple mechanisms by which B cells contribute to chronic inflammatory autoimmune diseases suggested that B cell depletion could be an effective approach for treating these diseases. Indeed, rituximab, a B cell-depleting anti-CD20 monoclonal antibody that was first developed for the treatment of B-cell malignancies, is now a standard therapy for rheumatoid arthritis (Edwards and Cambridge, 2006). B-cell depletion with monoclonal antibodies against B cell-specific membrane proteins such as CD20 and CD22 is also being considered as a treatment for a variety of other B cell-mediated autoimmune diseases (Kazkaz and Isenberg, 2004; Fiorina et al., 2008; Chan and Carter, 2010). The neutralization of BAFF, a cytokine that promotes the survival of B-2 and MZ B cells may also be a useful approach for depleting autoreactive B cells. Patients with rheumatoid arthritis (Baker, 2004) and SLE (Lebien and Tedder, 2008) exhibit elevated serum levels of BAFF and mice overexpressing BAFF develop SLE-like syndrome with expanded B-cell populations, elevated levels of anti-DNA antibodies, and immune complex deposition in the kidney (Mackay et al., 1999; Khare et al., 2000). In NOD mice, in vivo neutralization of BAFF reduces the level of autoantibodies against insulin, decreases the severity of islet inflammation, and reduces the incidence of spontaneous type
1 diabetes (Zekavat et al., 2008). Although global B-cell depletion holds promise as a treatment for autoimmunity, the strong association between autoimmunity and the expansion of innatelike B cells with inherent self-reactivity suggests that inhibiting the activation and function of the human equivalents of $\mathrm{MZ} \mathrm{B}$ cells and B-1 cells may be an important consideration for effectively treating B cell-mediated autoimmune diseases. In mouse models of autoimmune disease, there is evidence suggesting that selectively targeting innate-like $\mathrm{B}$ cell populations can reduce disease incidence and progression. For example, in $(\mathrm{NZB} \times \mathrm{NZW}) \mathrm{F}_{1}$ mice, which spontaneously develop autoimmune disease that is very similar to SLE in humans, B-1 cell depletion delays disease onset and reduces disease severity (Murakami et al., 1995), as does depletion of B-1 and MZ B cells using B-cell super antigens (Viau and Zouali, 2005). Similarly, as mentioned above, the somewhat-selective depletion of MZ B cells reduces disease incidence in a mouse model of type 1 diabetes (Noorchashm et al., 1999b). Thus, targeting MZ and B-1 B cells could be a useful approach for treating B cell-mediated autoimmune inflammatory diseases.

\section{TARGETING PI3K $\delta$ TO TREAT AUTOIMMUNITY}

Although a number of different approaches have been used to treat autoimmune diseases, there are currently no curative therapies and it appears that a combination of approaches may be needed to provide effective and long-term protection from disease progression. In the context of treating type 1 diabetes, Luo et al. (2010) have provided a critical analysis of past and current strategies for treating autoimmunity by targeting immune cells. In particular, agents that deplete B cells (e.g., the anti-CD20 monoclonal antibody rituximab) are now being investigated as therapies for B cell-mediated autoimmune diseases. Mouse models of disease first showed the potential of this approach. The incidence of spontaneous autoimmune diabetes in NOD mice can be reduced by depleting $\mathrm{B}$ cells with anti-IgM-specific antibodies (Noorchashm et al., 1997), antibodies to CD20 (Hu et al., 2007; Xiu et al., 2008), anti-CD22 antibodies conjugated to a cytotoxic agent (Fiorina et al., 2008), or a fusion protein that sequesters the B-cell survival cytokine BAFF (Marino and Grey, 2008; Zekavat et al., 2008). Similar results have been obtained in other mouse models of autoimmunity (Yu et al., 2008). B-cell depletion with rituximab has now been tested in patients with a variety of B cell-mediated autoimmune diseases, with some success (Kazkaz and Isenberg, 2004; Martin and Chan, 2006; Sanz et al., 2007; Pescovitz et al., 2009; Hegedus et al., 2011). In a phase 2 clinical trial, rituximab treatment partially preserved beta cell function in patients with type 1 diabetes (Pescovitz et al., 2009). This incomplete efficacy could be due the variable penetration of monoclonal antibodies into tissues, resulting in poor depletion on innate-like B cell subsets (Gong et al., 2005; Yu et al., 2008). Moreover, the use of antibodies for treating chronic autoimmune diseases has been associated with infusion site reactions and other adverse reactions caused by immune complex formation (Vogel, 2010; El Fassi et al., 2011). A more serious issue associated with B-cell depletion as a long-term treatment approach for treating autoimmune diseases is chronic immunosuppression (Luo et al., 2010), as well as the potential 
for eliminating beneficial B cells such as the recently identified "Bregs" that produce IL-10 and limit autoimmune reactions (Mizoguchi and Bhan, 2006; Matsushita et al., 2008). Indeed, in two mouse models of experimental autoimmune encephalomyelitis, anti-CD20-induced B-cell depletion increased the severity of the disease (Weber et al., 2010). The caveats associated with antibody-mediated B-cell depletion strategies suggest that small molecule inhibitors of B-cell function that are orally available, have good tissue penetration, and whose effects are reversible over a short period of time (in contrast to causing long-term immunosuppression) may allow for "tunable" moderate levels of B cell inhibition that can preserve beneficial B-cell functions while having limited side effects over the prolonged treatment course for chronic autoimmune diseases. Such B-cell inhibitors could be useful for managing disease, but may also be useful as an adjunct to rituximab, perhaps by reducing the frequency at which B-cell depletion would need to be done.

Based on the findings described earlier, there are a number of reasons why $\mathrm{PI} 3 \mathrm{~K} \delta$ is a very promising target for the treatment of autoimmune inflammatory diseases, particularly those in which B cells play a major role. By blocking B-cell migration, adhesion, survival, activation, and proliferation, inhibition of p110 8 activity would impair the ability of B cells to act as APCs that activate autoreactive $\mathrm{T}$ cells, prevent their activation, and reduces their secretion of autoantibodies and pro-inflammatory cytokines. Moreover, innate-like B cells, which have been strongly linked to autoimmunity, appear to be the most sensitive to loss of PI3K $\delta$ activity as MZ and B-1 cells are nearly absent in mice lacking a functional p $110 \delta$ gene. We have directly shown that PI3K $\delta$ inhibitors reduce the trafficking and activation of $\mathrm{MZ}$ and $\mathrm{B}-1$ cells in vitro, as well as the localization of $\mathrm{MZ} B$ cells in mice (Durand et al., 2009). Importantly, the restricted expression of p110 $\delta$ mainly in hematopoietic cells, the observation that B cells are the cell type most impaired in mice lacking a functional version of p110 $\delta$, and phase I clinical trial data showing that the PI3K $\delta$ inhibitor GS-1101 is safe and well-tolerated by patients (Kahl et al., 2010) indicate that these compounds can be used to modulate B-cell function in vivo without deleterious effects on other cell types or significant side effects. As a proof-of-principle that PI3K $\delta$ inhibitors can inhibit B cell-mediated autoimmune reactions in vivo, we showed that administering IC87114 to rats reduces autoantibody production in a model of collagen-induced arthritis (Durand et al., 2009).

PI3K $\delta$ inhibitors such as IC87114 have now been shown to reduce the incidence and severity of autoimmune arthritis (Randis et al., 2008), asthma (Lee et al., 2006; Park et al., 2010), experimental autoimmune encephalomyelitis (HaylockJacobs et al., 2011), and SLE (Maxwell et al., 2012) in mouse models. Our current work suggests that oral administration of IC87114 opposes the progression of autoimmune diabetes in NOD mice. The ability of PI3K $\delta$ inhibitors to reduce the severity of these inflammatory diseases may be due not only to their actions on innate-like B cells, but also to inhibitory effects on other immune cells that contribute to autoimmune disease (Fung-Leung, 2011). IC87114 inhibits the trafficking of neutrophils into inflamed tissues (Puri et al., 2004) and prevents the activation of mast cells (Ali et al., 2004, 2008). PI3K $\delta$ also plays an important role in TCR-induced T-cell activation (Okkenhaug et al., 2002, 2006) and IC87114 treatment inhibits TCR-induced cytokine production by both naïve and memory human $\mathrm{T}$ cells in vitro (Soond et al., 2010). In particular, p110 signaling is important for IL-17 production by both mouse and human T cells (Park et al., 2010; Soond et al., 2010; Haylock-Jacobs et al., 2011). IL-17-producing $\mathrm{T}_{\mathrm{H}} 17$ cells have been implicated in a number of autoimmune diseases (Jain et al., 2008; Emamaullee et al., 2009; Crome et al., 2010). Finally, PI3K $\delta$ mediates the TCR-induced downregulation of CD62L (Sinclair et al., 2008), which is required for the trafficking of activated $\mathrm{T}$ cells into tissues. The broad spectrum of action against cells that contribute to autoimmune processes, combined with the limited expression of p1108 in nonhematopoietic tissues, suggests that $\mathrm{PI} 3 \mathrm{~K} \delta$ inhibitors could have an excellent therapeutic index for the treatment of autoimmune diseases.

Providing a further rationale for the use of PI3K $\delta$ inhibitors to treat autoimmune disease is the recent finding that enhanced $\mathrm{PI} 3 \mathrm{~K} \delta$ activity is associated with autoimmunity in humans (Suarez-Fueyo et al., 2011). PI3K $\delta$ activity is significantly increased compared to normal individuals in T cells from $\sim 70 \%$ of SLE patients, and this difference is greatest in patients with active disease. Consistent with a role for PI3K in promoting cell survival, SLE patients exhibit an expanded population of CD4+ memory T cells, as well as defective activation-induced cell death (AICD) of T cells, a defect that can be corrected in vitro by pharmacological inhibition of p110 $\delta$ with IC87114. AICD normally limits the expansion of activated $\mathrm{T}$ cells and terminates immune responses. Defects in AICD, for example in mice or humans with loss-of-function mutations in Fas or FasL, are strongly correlated with autoimmunity. This suggests that excessive activation of PI $3 K \delta$ could contribute to the T cell dysregulation associated with SLE. In this case, $\mathrm{PI} 3 \mathrm{~K} \delta$ inhibitors may be useful for treating SLE, for which there is currently no effective cure or treatment. The basis for the excessive PI3K $\delta$ activity in SLE patients is not known nor is it known whether aberrant PI $3 \mathrm{~K} \delta$ activity is associated with other autoimmune diseases.

For treating autoimmune diseases, the therapeutic effects of inhibiting PI3K $\delta$ could potentially be enhanced by simultaneously inhibiting PI3K $\gamma$ (Rommel et al., 2007). In addition to participating in the activation of T cells through the TCR, PI3K $\gamma$ signaling is essential for neutrophils and macrophages to invade tissues and produce inflammatory mediators (Hirsch et al., 2000; Sasaki et al., 2000; Alcazar et al., 2007). Like p110 , p110 $\gamma$ is expressed mainly in hematopoietic cells, such that selective inhibition of PI3K isoforms containing these catalytic subunits would have limited toxicity on other cell types. Treating mice with the PI3K $\gamma$-selective inhibitor AS605240 can reduce disease incidence and severity in mouse models of rheumatoid arthritis, SLE, and type 1 diabetes (Barber et al., 2005; Camps et al., 2005; Azzi et al., 2012), implicating $\mathrm{PI} 3 \mathrm{~K} \gamma$ in these disease processes and suggesting that $\mathrm{PI} 3 \mathrm{~K} \gamma$, like $\mathrm{PI} 3 \mathrm{~K} \delta$, is a good therapeutic target for treating autoimmune diseases. Abdi and colleagues (Azzi et al., 2012) provided several mechanistic insights into how inhibition of PI3K $\gamma$ may prevent the progression of autoimmune diabetes in NOD mice. Both in vitro and in vivo studies showed that AS605240 inhibited the expansion and effector functions (e.g., cytokine production) of 
autoreactive CD4+ T cells while expanding the number of regulatory $\mathrm{T}$ cells (Tregs), consistent with previous findings that PI3K inhibition causes $\mathrm{T}$ cells to become Tregs instead of T-effector cells (Haxhinasto et al., 2008; Sauer et al., 2008) This shift in the $\mathrm{T}_{\text {eff }} /$ Treg balance toward a more immunoregulatory or immunosuppressive state correlated with a delayed onset of diabetes in NOD mice. Importantly, similar to our preliminary findings with the $\mathrm{PI} 3 \mathrm{~K} \delta$ inhibitor IC87114, treating NOD mice with the PI3K $\gamma$ inhibitor when they first exhibited elevated blood glucose levels provided sustained protection from progression to overt diabetes in a number of animals (Azzi et al., 2012). These findings suggest that combined inhibition of $\mathrm{PI} 3 \mathrm{~K} \gamma$ and $\mathrm{PI} 3 \mathrm{~K} \delta$ could have even greater efficacy in preventing diabetes progression. Recently described dual inhibitors of PI3K $\gamma$ and PI3K $\delta$ (Williams et al., 2010) could therefore hold substantial promise as a therapeutic approach for preventing disease progression in patients with early-stage type 1 diabetes and perhaps other chronic autoimmune inflammatory diseases. However dual inhibition of PI3K $\gamma$ and PI3K $\delta$ may need to be carefully titrated, as loss of both $\mathrm{PI} 3 \mathrm{~K} \gamma$ and $\mathrm{PI} 3 \mathrm{~K} \delta$ activity in mice is associated with a shift in the $\mathrm{T}_{\mathrm{h} 2} / \mathrm{T}_{\mathrm{h} 1}$ balance that leads to eosinophil-mediated multi-organ inflammation (Ji et al., 2007).

The successful use of PI3K $\gamma / \delta$ inhibitors to treat inflammatory autoimmune diseases must take into account the need to balance suppression of autoimmune responses with maintenance of protective immunity as well as the potential for unexpected pro-inflammatory consequences of $\mathrm{PI} 3 \mathrm{~K} \gamma / \delta$ inhibition, as has been observed in mice. As mentioned above, eosinophil-mediated inflammation is associated with the loss of both PI3K $\gamma$ and PI3K $\delta$ activity in mice (Ji et al., 2007). Moreover, loss of PI3K $\delta$ activity in mice greatly enhances isotype switching to IgE (Zhang et al., $2008,2012)$, which could lead to atopic reactions. It remains to be seen whether these pro-inflammatory consequences of PI3K $\gamma / \delta$ inhibition occur in humans. The paradoxical effects of PI3K $\delta$ inhibition on Tregs, cells that play a critical role in limiting autoimmune reactions, may also be an important factor to consider. Inhibition of PI3K $\delta$ activity has been reported to impair Treg function, even though it promotes Treg development (Patton et al., 2006; Sauer et al., 2008; Okkenhaug and Fruman, 2010). Despite these caveats, phase I clinical trial data have shown that the PI3K $\delta$ inhibitor GS-1101 is safe and well-tolerated by patients (Kahl et al., 2010). Thus optimized dosing regimens that cause partial inhibition of $\mathrm{PI} 3 \mathrm{~K} \gamma / \delta$ may have the ability to substantially inhibit autoimmune reactions without rendering protective immune responses ineffective or causing significant unwanted side effects.

\section{PI3K $\delta$ AS A TARGET FOR TREATING B-CELL MALIGNANCIES}

In addition to a key role for PI3K $\delta$ in autoimmune inflammation, this pathway has emerged as a central mechanism underlying the survival and expansion of various malignant B-cells. BCR signaling is a central pathologic mechanism in B-cell malignancies, including chronic lymphocytic leukemia (CLL), diffuse large Bcell lymphoma (DLBCL) (Davis et al., 2010), and mantle cell lymphoma (MCL). Comparative gene expression profiling data demonstrate that BCR signaling is the most prominent pathway activated in CLL cells isolated from lymphatic tissues (Herishanu et al., 2011). Similarly, MCL cells display signs of constitutive activation of BCR (Rinaldi et al., 2006; Cecconi et al., 2008; Pighi et al., 2011) and PI3K signaling (Martinez et al., 2003; Rizzatti et al., 2005) in the absence of activating mutations. The role of BCR-induced PI3K signaling in promoting the survival of malignant $\mathrm{B}$ cells, combined with the fact that $\mathrm{PI} 3 \mathrm{~K} \delta$ is the predominant $\mathrm{PI} 3 \mathrm{~K}$ isoform involved in $\mathrm{BCR}$ signaling, make this $\mathrm{PI} 3 \mathrm{~K}$ isoform a very promising target for the treatment of B-cell cancers. Substantial progress, both preclinical and clinical, has been made with GS-1101 (CAL-101), a selective inhibitor of the $\mathrm{PI} 3 \mathrm{~K} \delta$ pathway. The importance of the $\mathrm{PI} 3 \mathrm{~K} \delta$ pathway in B cells, as well as the initial development of GS-1101 as a treatment for B-cell malignancies, has been reviewed recently by Fruman and Rommel (2011).

\section{ROLE OF PI3K $\delta$ SIGNALING IN B-CELL MALIGNANCIES}

The potential role of excessive PI3K signaling in the development of B-cell malignancies was initially reported by Borlado et al. (2000), who showed that mice expressing a constitutively active form of PI3K develop infiltrating lymphoproliferative disorders as well as autoimmune disease. There is now mounting evidence for the importance of PI3K signaling in B-cell malignancies. Uddin et al. (2006) demonstrated the constitutive activation of the PI3K pathway in several DLBCL cell lines, importantly, in primary cells from the majority of patients with DLBCL. Constitutive activation of the PI3K pathway, as measured by elevated levels of phospho-Akt, has also been demonstrated in MCL cell lines and in primary cells from patients with MCL (Rudelius et al., 2006). PI3K activation has also been observed in follicular lymphoma (FL), mediastinal DLBCL, and Hodgkin's lymphoma (Renne et al., 2007; Garcia-Martinez et al., 2011). More recently, a role for the PI3K $\delta$ isoform in the pathophysiology of B-cell malignancies has emerged. Several experiments have shown that there is excessive p110 $\delta$ activity in malignant lymphoid cells. Herman et al. (2010) showed that there were significantly higher levels of PI3K p $110 \delta$ activity in primary cells from patients with CLL than in normal hematopoietic cells. Similarly, PI3K p110 is hyperactivated in plasma cell myeloma (PCM) cell lines and malignant cells from patients with PCM (Ikeda et al., 2010). Excessive PI3K $\delta$ activity has also been observed in cell lines and primary cells from patients with Hodgkin's lymphoma (Meadows et al., 2012).

The development of GS-1101, a potent and selective inhibitor of PI3K p110 $\delta$, has enhanced our understanding of the role of p110 $\delta$ in B-cell malignancies. GS-1101 (5-Fluoro-3-phenyl2-[(S)-1-(9H-purin-6-ylamino)-propyl]-3H-quinazolin-4-one) inhibits $\mathrm{PI} 3 \mathrm{~K}$ p $110 \delta$ with an $\mathrm{IC}_{50}$ value of $2.5 \mathrm{nM}$ in vitro whereas its $\mathrm{IC}_{50}$ values for the $\mathrm{p} 110 \alpha, \mathrm{p} 110 \beta$ and $\mathrm{p} 110 \gamma$ subunits are 820 , 565 and $89 \mathrm{nM}$, respectively (Lannutti et al., 2011). GS-1101 also shows a greater selectivity for inhibition of $\mathrm{p} 110 \delta$ than for mTOR and other related kinases, and demonstrates high selectivity for p110 $\delta$ when tested against a panel of more than 400 diverse kinases (Lannutti et al., 2011). Additionally, in isoform-specific cell-based assays, GS-1101 blocks $\mathrm{PI} 3 \mathrm{~K} \delta$-dependent responses at concentrations that are $>240$-fold lower than those required to inhibit responses that are dependent on other PI3K isoforms (Lannutti et al., 2011). In addition to GS-1101, several other 
$\mathrm{PI} 3 \mathrm{~K} \delta$ inhibitors are now in clinical trials and many more are in preclinical development, as described in a recent review (Norman, 2011).

The mechanism of action of GS-1101 has been studied in cell lines and primary patient samples representing diverse B-cell malignancies including CLL, DLBCL, and multiple myeloma (MM) (Herman et al., 2010; Ikeda et al., 2010; Hoellenriegel et al., 2011; Lannutti et al., 2011). Primary cells derived from CLL patients have high levels of p110 $\delta$ and treating these cells with low micromolar concentrations of GS-1101 promotes apoptosis through caspase activation (Herman et al., 2010). This cytotoxic effect of GS-1101 is independent of the $\operatorname{IgV}_{\mathrm{H}}$ mutational status of the cells as well as interphase cytogenetic abnormalities, the common prognostic factors associated with poor response to therapy in CLL. Interestingly, GS-1101 inhibits not only constitutive PI3K signaling in these cells but also antagonizes CLL cell survival by blocking the protective effect of CD40-ligand (CD40L) and microenvironmental stimuli (Herman et al., 2010). In particular, the cytokines BAFF and TNF $\alpha$ enhance the survival of primary CLL cells in vitro but this effect is attenuated by submicromolar concentrations of GS-1101 (Herman et al., 2010). Similarly, the survival advantage conferred to CLL cells by growth on fibronectin or stromal cell layers is reversed by GS-1101 (Herman et al., 2010).

More recent work demonstrated that GS-1101 completely blocks survival signals mediated by BCR engagement and significantly reduces survival of CLL cells cultured on specialized nurse-like cells (NLC) derived from peripheral blood monocytes (Hoellenriegel et al., 2011). Furthermore, GS-1101 decreases the secretion of survival-associated chemokines by both the CLL cells (CCL2, CCL3) and stromal cells (CXCL13) in a co-culture model. The co-culture of CLL and NLC triggers the release of additional survival factors (CCL7, CCL17, CCL22, soluble CD40L, IL-6, and TNF $\alpha$ ) whose secretion is also reduced by GS1101. Additionally, GS-1101 inhibits CLL cell chemotaxis toward CXCL12 and CXCL13. These chemokines are commonly present in the B-cell follicles of lymph nodes and chemoattract CLL cells to this protective microenvironment. Together these observations suggest that $\mathrm{PI} 3 \mathrm{~K} \delta$ inhibition with GS-1101 can antagonize intrinsic survival signals and also block survival signals provided by extrinsic factors in the tumor microenvironment.

$\mathrm{PI} 3 \mathrm{~K} \delta$ plays an essential role in PCM cell function (Ikeda et al., 2010). All PCM cell lines express p110 $\delta$ and treatment with micromolar concentrations of GS-1101 inhibits the constitutive phosphorylation of Akt observed in these cells. This correlates

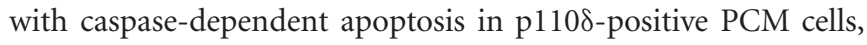
with minimal cytotoxicity in p110 $\delta$-negative cells (Ikeda et al., 2010). IL-6 and IGF-1, which are present in the bone marrow (BM) microenvironment, promote MM cell proliferation and survival. Importantly, the cytotoxic effect of GS-1101 on PCM cells was not diminished in the presence of IL-6 and IGF-1, suggesting that GS-1101 can overcome the protective effects of these cytokines within the BM milieu. GS-1101 also exhibits an inhibitory effect on PCM cells in the presence of BM stromal cells (BMSCs), and inhibited the growth, cytokine production, and Akt phosphorylation that are induced in PCM cells by their association with BMSCs (Ikeda et al., 2010).

\section{PI3K p1108 INHIBITION WITH GS-1101 IN PATIENTS WITH B-CELL MALIGNANCIES}

GS-1101 was the first selective inhibitor of PI3K $\delta$ to enter clinical testing for various B-cell malignancies including CLL, nonHodgkin lymphoma (NHL), acute myeloid leukemia (AML), DLBCL, and MM. Remarkably, treatment with GS-1101 as a single agent provided durable remissions to a significant percentage of patients with CLL and certain subtypes of NHL (Sharman et al., 2011). Most of these patients had relapsed from multiple other treatment regimens yet responded to the p $110 \delta$ inhibitor. GS-1101 also showed impressive efficacy when combined with standard-of-care agents (e.g., rituximab, bendamustine, and fludarabine) for indolent NHL (iNHL) and CLL. Currently GS-1101 has advanced to phase 3 clinical testing in CLL as a single agent or in combination with rituximab and bendamustine (clinical trial identifiers: NCT01569295, NCT01539291, and NCT01539512). In addition, an ongoing phase 2 clinical study is evaluating the efficacy and safety of GS-1101 in patients with relapsed or refractory Hodgkin lymphoma (clinical trial identifier: NCT01393106).

Although most of the data have not yet been published in peerreviewed journals, some of the clinical data for trials involving GS-1101 have been presented at meetings over the past few years and described in abstracts of the conference proceedings (Flinn et al., 2009a,b,c; Brown et al., 2010; Flinn et al., 2010; Furman et al., 2010a; Kahl et al., 2010; de Vos et al., 2011; Kahl et al., 2011; Leonard et al., 2011; Sharman et al., 2011). Most recently, Miller and colleagues (Sharman et al., 2011) reported on a phase I study of GS-1101 as single agent and in combination with rituximab and/or bendamustine in patients with relapsed/refractory CLL (clinical trial identifiers: NCT00710528 and NCT01088048). Data were presented from 55 patients with CLL who were administered GS-1101 monotherapy and 54 patients who received GS-1101based combination therapies. GS-1101 as single agent or as part of a combination therapy caused lymph node shrinkage in a large majority of CLL patients (>79\%) across all dose levels. Nodal size changes occurred in two phases: a steep initial reduction $(>50 \%$ reduction by week 8 ) that was followed by a persistent continuing decline over several months. The extent and kinetics of the nodal responses were similar in patients treated with single-agent GS-1101 or with combination therapies. A significant percentage of patients showed durable responses (approximately 25\% overall response rate) with single-agent GS-1101 and remained on study for many cycles of treatment. GS-1101-based combinations substantially increased the overall response rate to $81 \%$ compared to single-agent therapy. The median progression-free survival in patients on GS-1101 monotherapy was >12 months and the median progression-free survival for any combination therapy has not yet been reached but has exceeded 12 months.

The initial lymph node reduction observed in the majority of CLL patients treated with single-agent GS-1101 was accompanied by a transient elevation in circulating lymphocyte counts (Sharman et al., 2011), a phenomenon known as lymphocytosis. This lymphocytosis resolved over several months of continued GS-1101 treatment. This redistribution of CLL cells from the tissues into the blood is likely the result of lymphocytes being released from lymphoid tissue microenvironments or failing to home from the blood into lymph nodes, resulting in the 
eventual death of tumor cells that are prevented by GS-1101 from accessing the supportive microenvironment of the lymph nodes. Importantly, the pattern and extent of lymphocytosis in CLL patients were altered by combination therapy. The combination of GS-1101 with rituximab or fludarabine led to a shorter duration of lymphocytosis while the combination with bendamustine largely eliminated the increase in circulating lymphocyte counts (Sharman et al., 2011).

The CLL patients treated with GS-1101 monotherapy and combination therapy also showed significantly reduced plasma levels of the chemokines CXCL13, CCL3, CCL4 and cytokine $\mathrm{TNF} \alpha$ after 28 days of treatment compared with pretreatment measurements, further suggesting disruption of the CLL microenvironment by GS-1101 (Hoellenriegel et al., 2011; Sharman et al., 2011). As described earlier, previous studies demonstrated an important role for $\mathrm{PI} 3 \mathrm{~K} \delta$ in B-cell adhesion, migration, and homing to lymphatic tissues (Reif et al., 2004; Durand et al., 2009). B cells from PI3K p1108 knockout mice respond poorly to CXCL13, and exhibit reduced homing to lymphatic tissues in adoptive transfer experiments (Reif et al., 2004). PI3K $\delta$ activity is also required for chemotactic and adhesive signals that mediate the localization of B cells in lymphoid tissue, as indicated by the ability of in vitro IC87114 treatment to inhibit B cell chemotaxis toward CXCL13 and S1P as well as CXCL13-stimulated adhesion to ICAM-1, which is mediated by the LFA-1-integrin (Durand et al., 2009). Consistent with this, treating mice with IC87114, a selective PI3K $\delta$ inhibitor (Sadhu et al., 2003b), disrupted the in vivo localization of MZ B cells in mice (Durand et al., 2009). Indeed, the notable clinical activity of GS-1101 in CLL is associated with mobilization of CLL cells from tissues into the blood, which results in pronounced lymph node shrinkage and transient lymphocytosis. Thus GS-1101 displays a dual mechanism of action against CLL, directly decreasing BCR-induced CLL cell survival (see above) and inhibiting chemokine-dependent interactions that retain CLL cells in survival-promoting tissue microenvironments. These combined actions may account for the ability of this $\mathrm{PI} 3 \mathrm{~K} \delta$ inhibitor to sensitize CLL cells to the current standard-of-care agents. Similar effects have been observed with inhibitors of the Syk, Btk, and mTOR kinases, which also function in both chemokine receptor and BCR signaling pathways (Friedberg et al., 2010; Zent et al., 2010; Burger, 2012; de Rooij et al., 2012). The common mechanism underlying the antitumor activity of these kinase inhibitors that are active against CLL may be their ability to inhibit multifunctional signaling pathways that control leukemia cell survival, adhesion, migration, and homing.

Similar promising results have been obtained in a phase 1 study (de Vos et al., 2011) of GS-1101 as a single agent and in combination with rituximab and/or bendamustine for treatment of patients with relapsing/remitting iNHL (clinical trial identifiers: NCT00710528 and NCT01088048). Data were presented from 63 patients with iNHL on GS-1101 monotherapy and 52 patients on GS-1101-based combination therapies representing all four subtypes of iNHL: follicular, small lymphocytic, lymphoplasmacytic, and MZ, with FL being the most common in all treatment arms. GS-1101 as single agent or as combination therapy caused substantial tumor regression in a large majority of patients with indolent NHL and across all dose levels. The overall response rate for GS-1101 monotherapy was 38\% across all dose levels and 59\% at doses $\geq 100 \mathrm{mg}$ twice daily. GS-1101-based combinations substantially increased the overall response rate to $83 \%$ compared to single-agent therapy. Furthermore, complete remission was achieved in 15-25\% of patients on GS-1101-based combination therapies. Similar to clinical data in CLL, both GS1101 monotherapy and combination therapy were associated with durable tumor control with the median progression-free survival in patients receiving GS-1101 monotherapy at doses $\geq$ $100 \mathrm{mg}$ twice daily, receiving any combination therapy, was $>12$ months.

Consistent with observations in CLL patients, treatment of iNHL patients with single-agent GS-1101 or combinations significantly decreased plasma levels of CCL17, CCL22, CXCL13, and $\mathrm{TNF} \alpha$. However, unlike the biphasic nodal response and transient lymphocytosis observed in CLL patients treated with GS-1101 monotherapy, iNHL patients show profound and rapid reductions in lymph nodes. The lymphocytosis has not been reported in patients with iNHL treated with single-agent GS-1101 or with combination therapies, suggesting that redistribution of cells to the periphery may not be a critical mechanism of antitumor activity of GS-1101 in iNHL. This is also consistent with the observation that iNHL cells are not generally found in circulation; hence, they are likely being cleared in the tissue sites rather than in the periphery.

GS-1101 has also been tested as a single agent treatment in a small number of patients (9-11 each) with MM, AML, and DLBCL malignancies. However, as reported in conference proceeding abstracts, it has not shown the same level of efficacy as for CLL and NHL (Flinn et al., 2009a; Furman et al., 2010b; Kahl et al., 2010). Because the effects of GS-1101 on the redistribution of malignant cells and on plasma chemokine and cytokine levels in these patients has not been reported, it is not known if the lack of efficacy was due to insufficient inhibition of the PI3K pathway or to protective microenvironmental signals in these malignancies. Whether GS-1101 treatment would make these malignant cells more susceptible to other standard-of-care treatments remains to be determined.

An important consideration for therapeutics that target signaling pathways that are essential for the survival and dissemination of malignant lymphocytes is whether they will also suppress beneficial anti-tumor immunity. Several studies have reported that $\mathrm{PI} 3 \mathrm{~K} \delta$ is required for the function of immune cells that could influence the immune response to tumor cells. GS-1101 strongly suppresses cytokine production by human T cells (Herman et al., 2010). Moreover, inhibition of PI3K $\delta$ may also have detrimental effects on tumor immunosurveillance by NK cells and cytotoxic $\mathrm{T}$ lymphocytes (CTL). PI3K $\delta$ activity is important for NK cell activation and function (Kim et al., 2007; Saudemont et al., 2007) and for induction of both the perforin-granzyme and deathreceptor pathways of CTL-mediated tumor cell killing (Putz et al., 2012). In addition, Tregs play a key role in restraining immune responses including anti-tumor responses but the net effect of PI3K $\delta$ inhibition on Tregs is still unclear. Loss of PI3K $\delta$ activity promotes the differentiation of $\mathrm{T}$ cells into Tregs but can also inhibit Treg function (Patton et al., 2006; Sauer et al., 2008; 
Okkenhaug and Fruman, 2010). Thus determining how to balance inhibition of malignant cell survival with maintenance of anti-tumor immunity will be the key to treatment success.

\section{CONCLUSIONS}

Recent data has demonstrated that the PI3K $\delta$ pathway is a critical signaling circuit in B cells and plays a key role in autoimmune inflammation as well as some lymphoid malignancies. This pathway is hyperactivated in various B-cell malignancies and its inhibition with $\mathrm{PI} 3 \mathrm{~K} \delta$-targeted compound has achieved promising clinical responses in patients with CLL, iNHL, and other B-cell neoplasia. The PI3K $\delta$ inhibitor GS1101 appears to antagonize both intrinsic and extrinsic cell survival signals, decreases the survival of CLL cells directly, and abrogates cellular interactions between CLL cells and components of the tissue microenvironment that normally sustain leukemia and lymphoma cells in a protective niche. Ongoing clinical studies are further characterizing the risks and benefits of long-term PI3K $\delta$ inhibition. Nevertheless, the initial trials suggest that GS-1101 has significant potential both as a single agent and in combination with bendamustine and rituximab for the treatment of CLL and iNHL (clinical trial identifiers: NCT01569295, NCT01539512, and NCT01539291). Ongoing clinical studies are also evaluating GS1101 to potentially expand its utility in additional B-cell malignancies such as Hodgkin's lymphoma (clinical trial identifier: NCT01393106).

\section{REFERENCES}

Al-Alwan, M. M., Okkenhaug, K., Vanhaesebroeck, B., Hayflick, J. S., and Marshall, A. J. (2007). Requirement for phosphoinositide 3-kinase p110delta signaling in $\mathrm{B}$ cell antigen receptor-mediated antigen presentation. J. Immunol. 178, 2328-2335.

Alcazar, I., Marques, M., Kumar, A., Hirsch, E., Wymann, M., Carrera, A. C., and Barber, D. F. (2007). Phosphoinositide 3-kinase gamma participates in $\mathrm{T}$ cell receptorinduced T cell activation. J. Exp. Med. 204, 2977-2987.

Ali, K., Bilancio, A., Thomas, M., Pearce, W., Gilfillan, A. M., Tkaczyk, C., Kuehn, N., Gray, A., Giddings, J., Peskett, E., Fox, R., Bruce, I., Walker, C., Sawyer, C., Okkenhaug, K., Finan, P., and Vanhaesebroeck, B. (2004). Essential role for the p110delta phosphoinositide 3kinase in the allergic response. Nature 431, 1007-1011.

Ali, K., Camps, M., Pearce, W. P., Ji, H., Ruckle, T., Kuehn, N., Pasquali, C., Chabert, C., Rommel, C., and Vanhaesebroeck, B. (2008). Isoform-specific functions of phosphoinositide 3-kinases: p110 delta but not p110 gamma promotes optimal allergic responses in vivo. J. Immunol. 180, 2538-2544.

Attanavanich, K., and Kearney, J. F. (2004). Marginal zone, but not follicular B cells, are potent activators of naive CD4 T cells. J. Immunol. 172, 803-811.

Azzi, J., Moore, R. F., Elyaman, W., Mounayar, M., El Haddad, N., Yang, S., Jurewicz, M., Takakura, A., Petrelli, A., Fiorina, P., Ruckle, T., and Abdi, R. (2012). The novel therapeutic effect of phosphoinositide 3-kinase-gamma inhibitor AS605240 in autoimmune diabetes. Diabetes 61, 1509-1518.

Baker, K. P. (2004). BLyS-an essential survival factor for B cells: basic biology, links to pathology and therapeutic target. Autoimmun. Rev. 3, 368-375.

Barber, D. F., Bartolome, A., Hernandez, C., Flores, J. M., Redondo, C., Fernandez-Arias, C., Camps, M., Ruckle, T., Schwarz, M. K., Rodriguez, S., Martinez, A. C., Balomenos, D., Rommel, C., and Carrera, A. C. (2005). PI3Kgamma inhibition blocks glomerulonephritis and extends lifespan in a mouse model of systemic lupus. Nat. Med. 11, 933-935.

The $\mathrm{PI} 3 \mathrm{~K} \delta$ pathway is also constitutively activated in various inflammatory conditions and pharmacological inhibition or genetic inactivation of this pathway has demonstrated efficacy in several preclinical models of inflammation. Clinical studies are now evaluating the potential of PI $3 \mathrm{~K} \delta$ inhibitors for the treatment of a variety of inflammatory diseases (clinical trial identifiers: NCT00836914 and NCT01462617). In addition to B-cell inhibition, PI3K $\delta$ inhibitors are also likely to significantly impact differentiation, migration, and cytokine production by $\mathrm{T}$ cells as well as the degranulation of mast cells, suggesting that these agents may be effective beyond autoimmune diseases. As is the case for all immunosuppressive agents, a balance between suppressing autoimmunity and maintaining protective immunity needs to be established. Orally available small molecule inhibitors that have a short in vivo half-life would allow this balance to be adjusted in a continual manner.

In conclusion, PI3K $\delta$ plays a major role in both B-cellmediated inflammation and B-cell malignancies, and PI3K $\delta$ inhibitors therefore represent a promising therapeutic approach to treating these diseases.

\section{ACKNOWLEDGMENTS}

We thank Langdon Miller and Mary McGrath for helpful comments on the manuscript, David Ehlert of Cognition Studio for assistance preparing the figure, and Timothy J. DiChiara for technical writing assistance. PI3K research in the Gold lab has been funded by grants from the Canadian Institutes of Health Research.

Batista, F. D., and Harwood, N. E. (2009). The who, how and where of antigen presentation to B cells. Nat. Rev. Immunol. 9, 15-27.

Batten, M., Groom, J., Cachero, T. G., Qian, F., Schneider, P., Tschopp, J., Browning, J. L., and Mackay, F. (2000). BAFF mediates survival of peripheral immature B lymphocytes. J. Exp. Med. 192, 1453-1466.

Baumgarth, N. (2011). The double life of a B-1 cell: self-reactivity selects for protective effector functions. Nat. Rev. Immunol. 11, 34-46.

Bilancio, A., Okkenhaug, K., Camps, M., Emery, J. L., Ruckle, T., Rommel, C., and Vanhaesebroeck, B. (2006). Key role of the p110delta isoform of PI3K in B-cell antigen and IL-4 receptor signaling: comparative analysis of genetic and pharmacologic interference with pl10delta function in B cells. Blood 107, 642-650.

Binder, C. J., Chou, M. Y., Fogelstrand, L., Hartvigsen, K., Shaw, P. X. Boullier, A., and Witztum, J. L. (2008). Natural antibodies in murine atherosclerosis. Curr. Drug Targets 9, 190-195.

Borlado, L. R., Redondo, C., Alvarez, B., Jimenez, C., Criado, L. M., Flores, J., Marcos, M. A., Martinez, A. C.,
Balomenos, D., and Carrera, A. C. (2000). Increased phosphoinositide 3-kinase activity induces a lymphoproliferative disorder and contributes to tumor generation in vivo. FASEB J. 14, 895-903.

Bos, J. L. (2005). Linking Rap to cell adhesion. Curr. Opin. Cell Biol. 17, 123-128.

Brodie, G. M., Wallberg, M., Santamaria, P., Wong, F. S., and Green, E. A. (2008). B-cells promote intra-islet CD8+ cytotoxic T-cell survival to enhance type 1 diabetes. Diabetes 57, 909-917.

Brown, J., Byrd, J., Furman, R., Flinn, I., Benson, D., Coutre, S., Kahl, B., Wagner-Johnston, N., Spurgeon, S., Pratz, K., Giese, N., and Yu, O. A. (2010). Clinical activity in a phase 1 study of Cal-101, an isoform-selective inhibitor of phosphatidylinositol 3-kinase p110delta, in patients with B-cell malignancies. Haematol. Hematol. J. 95, 466.

Bugatti, S., Codullo, V., Caporali, R., and Montecucco, C. (2007). $B$ cells in rheumatoid arthritis. Autoimmun. Rev. 7, 137-142.

Burger, J. A. (2012). Inhibiting Bcell receptor signaling pathways in chronic lymphocytic leukemia. Curr. Hematol. Malig. Rep. 7, 26-33. 
Calamito, M., Juntilla, M. M., Thomas, M., Northrup, D. L., Rathmell, J., Birnbaum, M. J., Koretzky, G., and Allman, D. (2010). Akt1 and Akt2 promote peripheral B-cell maturation and survival. Blood 115, 4043-4050.

Camps, M., Ruckle, T., Ji, H., Ardissone, V., Rintelen, F., Shaw, J., Ferrandi, C., Chabert, C., Gillieron, C., Francon, B., Martin, T., Gretener, D., Perrin, D., Leroy, D., Vitte, P. A., Hirsch, E., Wymann, M. P., Cirillo, R., Schwarz, M. K., and Rommel, C. (2005). Blockade of PI3Kgamma suppresses joint inflammation and damage in mouse models of rheumatoid arthritis. Nat. Med. 11, 936-943.

Cecconi, D., Zamo, A., Bianchi, E., Parisi, A., Barbi, S., Milli, A., Rinalducci, S., Rosenwald, A., Hartmann, E., Zolla, L., and Chilosi, M. (2008). Signal transduction pathways of mantle cell lymphoma: a phosphoproteome-based study. Proteomics 8, 4495-4506.

Chan, A. C., and Carter, P. J. (2010). Therapeutic antibodies for autoimmunity and inflammation. Nat. Rev. Immunol. 10, 301-316.

Chen, J., Limon, J. J., Blanc, C., Peng, S. L., and Fruman, D. A. (2010). Foxol regulates marginal zone Bcell development. Eur. J. Immunol. 40, 1890-1896.

Chen, Y., Yu, M., Podd, A., Wen, R., Chrzanowska-Wodnicka, M., White, G. C., and Wang, D. (2008). A critical role of Raplb in B-cell trafficking and marginal zone B-cell development. Blood 111, 4627-4636.

Chou, M. Y., Hartvigsen, K., Hansen, L. F., Fogelstrand, L., Shaw, P. X., Boullier, A., Binder, C. J., and Witztum, J. L. (2008). Oxidationspecific epitopes are important targets of innate immunity. J. Intern. Med. 263, 479-488.

Cinamon, G., Matloubian, M., Lesneski, M. J., Xu, Y., Low, C., Lu, T., Proia, R. L., and Cyster, J. G. (2004). Sphingosine 1-phosphate receptor 1 promotes B cell localization in the splenic marginal zone. Nat. Immunol. 5, 713-720.

Clayton, E., Bardi, G., Bell, S. E., Chantry, D., Downes, C. P., Gray, A., Humphries, L. A., Rawlings, D., Reynolds, H., Vigorito, E., and Turner, M. (2002). A crucial role for the p110delta subunit of phosphatidylinositol 3-kinase in B cell development and activation. J. Exp. Med. 196, 753-763.

Crome, S. Q., Wang, A. Y., and Levings, M. K. (2010). Translational minireview series on Th17 cells: function and regulation of human $\mathrm{T}$ helper 17 cells in health and disease. Clin. Exp. Immunol. 159, 109-119.

Davis, R. E., Ngo, V. N., Lenz, G., Tolar, P., Young, R. M., Romesser, P. B., Kohlhammer, H., Lamy, L., Zhao, H., Yang, Y., Xu, W., Shaffer A. L., Wright, G., Xiao, W., Powell, J., Jiang, J. K., Thomas, C. J., Rosenwald, A., Ott, G., MullerHermelink, H. K., Gascoyne, R. D., Connors, J. M., Johnson, N. A., Rimsza, L. M., Campo, E., Jaffe, E. S., Wilson, W. H., Delabie, J., Smeland, E. B., Fisher, R. I., Braziel, R. M., Tubbs, R. R., Cook, J. R., Weisenburger, D. D., Chan, W. C., Pierce, S. K., and Staudt, L. M. (2010). Chronic active Bcell-receptor signalling in diffuse large B-cell lymphoma. Nature 463, 88-92.

Delgado, P., Cubelos, B., Calleja, E., Martinez-Martin, N., Cipres, A., Merida, I., Bellas, C., Bustelo, X. R., and Alarcon, B. (2009). Essential function for the GTPase TC21 in homeostatic antigen receptor signaling. Nat. Immunol. 10, 880-888.

de Rooij, M. F., Kuil, A., Geest, C. R. Eldering, E., Chang, B. Y., Buggy, J. J., Pals, S. T., and Spaargaren, M. (2012). The clinically active BTK inhibitor PCI-32765 targets B-cell receptor- and chemokinecontrolled adhesion and migration in chronic lymphocytic leukemia. Blood 119, 2590-2594.

de Vos, S., Schreeder, M. T., Flinn, I. W., Coutre, S. E., Leonard, J. P. Wagner-Johnston, N. D., Fowler, N. H., Boccia, R. V., Barrientos, J. C., Boyd, T., Sharman, J., Holes, L., Lannutti, B., Johnson, D. M., Jahn, T. M., and Miller, L. L. (2011). A phase 1 study of the selective phosphatidylinositol 3-kinase-delta (PI3K delta) inhibitor, cal-101 (GS1101 ), in combination with rituximab and/or bendamustine in patients with previously treated, indolent non-hodgkin lymphoma (iNHL). Blood 118, 1160.

Dil, N., and Marshall, A. J. (2009). Role of phosphoinositide 3-kinase p110 delta in TLR4- and TLR9mediated B cell cytokine production and differentiation. Mol. Immunol. 46, 1970-1978.

Donahue, A. C., and Fruman, D. A. (2004). PI3K signaling controls cell fate at many points in B lymphocyte development and activation. Semin. Cell Dev. Biol. 15, 183-197.

Duan, B., and Morel, L. (2006). Role of B-1a cells in autoimmunity. Autoimmun. Rev. 5, 403-408.

Durand, C. A., Hartvigsen, K., Fogelstrand, L., Kim, S., Iritani,
S., Vanhaesebroeck, B., Witztum, J. L., Puri, K. D., and Gold, M. R. (2009). Phosphoinositide 3-kinase p110 delta regulates natural antibody production, marginal zone and B-1 B cell function, and autoantibody responses. J. Immunol. 183 , 5673-5684.

Durand, C. A., Westendorf, J., Tse, K. W., and Gold, M. R. (2006). The Rap GTPases mediate CXCL13- and sphingosine1-phosphate-induced chemotaxis, adhesion, and $\mathrm{Pyk} 2$ tyrosine phosphorylation in B lymphocytes. Eur. J. Immunol. 36 2235-2249.

Edwards, J. C., and Cambridge, G. (2006). B-cell targeting in rheumatoid arthritis and other autoimmune diseases. Nat. Rev. Immunol. 6, 394-403

El Fassi, D., Nielsen, C. H., Junker, P., Hasselbalch, H. C., and Hegedus, L. (2011). Systemic adverse events following rituximab therapy in patients with Graves' disease. J Endocrinol. Invest. 34, e163-e167.

Emamaullee, J. A., Davis, J., Merani, S., Toso, C., Elliott, J. F., Thiesen, A., and Shapiro, A. M. (2009). Inhibition of Th17 cells regulates autoimmune diabetes in NOD mice. Diabetes 58, 1302-1311.

Falcone, M., Lee, J., Patstone, G., Yeung, B., and Sarvetnick, N. (1998). B lymphocytes are crucial antigenpresenting cells in the pathogenic autoimmune response to GAD65 antigen in nonobese diabetic mice. J. Immunol. 161, 1163-1168.

Fields, M. L., and Erikson, J. (2003). The regulation of lupus-associated autoantibodies: immunoglobulin transgenic models. Curr. Opin. Immunol. 15, 709-717.

Fiorina, P., Vergani, A., Dada, S. Jurewicz, M., Wong, M., Law, K., Wu, E., Tian, Z., Abdi, R. Guleria, I., Rodig, S., DunussiJoannopoulos, K., Bluestone, J., and Sayegh, M. H. (2008). Targeting CD22 reprograms B-cells and reverses autoimmune diabetes. Diabetes 57, 3013-3024.

Flinn, I. W., Byrd, J. C., Furman, R. R. Brown, J. R., Benson, D. M., Coutre, S. E., Kahl, B. S., Smith, B. D. Wagner-Johnston, N. D., Spurgeon, S. E., Giese, N. A., and Yu, A. S (2009a). Evidence of clinical activity in a phase I study of CAL-101, an oral P110 delta isoform-selective inhibitor of phosphatidylinositol 3Kinase, in patients with relapsed or refractory B-cell malignancies. Blood 114, 380.

Flinn, I. W., Byrd, J. C., Furman, R. R., Brown, J. R., Lin, T. S., Bello, C., Giese, N. A., and Yu, A. S. (2009b). Preliminary evidence of clinical activity in a phase I study of CAL-101, a selective inhibitor of the p110d isoform of phosphatidylinositol 3-kinase (P13K), in patients with select hematologic malignancies. J. Clin. Oncol. 27, abstract 3543

Flinn, W., Byrd, J., Furman, R., Brown, J., Lin, T., Bello, C., Giese, N., and Yu, A. (2009c). Preliminary evidence of clinical activity in a phase 1 study of cal-101, a potent selective inhibitor of the P110delta isoform of phosphatidylinositol 3-Kinase, in patient with B-cell malignancies. Haematol. Hematol. J. 94, 303.

Flinn, I. W., Schreeder, M. T., WagnerJohnston, N., Boccia, R. V., Leonard, J. P., Coutre, S. E., Holes, L. M., Peterman, S., and Yu, A. S. (2010). A phase 1 study of CAL-101, an isoform-selective inhibitor of phosphatidylinositol 3-Kinase P110 delta, in combination with rituximab and/or bendamustine in patients with relapsed or refractory B-cell malignancies. Blood 116, 1168

Friedberg, J. W., Sharman, J., Sweetenham, J., Johnston, P. B., Vose, J. M., Lacasce, A., SchaeferCutillo, J., De Vos, S., Sinha, R. Leonard, J. P., Cripe, L. D., Gregory, S. A., Sterba, M. P., Lowe, A. M. Levy, R., and Shipp, M. A. (2010). Inhibition of Syk with fostamatinib disodium has significant clinical activity in non-Hodgkin lymphoma and chronic lymphocytic leukemia. Blood 115, 2578-2585.

Fruman, D. A. (2004). Phosphoinositide 3-kinase and its targets in B-cell and T-cell signaling. Curr. Opin. Immunol. 16, 314-320.

Fruman, D. A., and Rommel, C. (2011). PI3Kdelta inhibitors in cancer: rationale and serendipity merge in the clinic. Cancer Discov. 1, 562-572.

Fruman, D. A., Snapper, S. B., Yballe, C. M., Davidson, L., Yu, J. Y., Alt, F. W., and Cantley, L. C. (1999). Impaired B cell development and proliferation in absence of phosphoinositide 3-kinase p85alpha. Science 283, 393-397.

Fung-Leung, W. P. (2011) Phosphoinositide 3-kinase delta (PI3Kdelta) in leukocyte signaling and function. Cell. Signal. 23, 603-608.

Furman, R. R., Byrd, J. C., Brown, J. R., Coutre, S. E., Benson, D. M., Wagner-Johnston, N. D., Flinn, I. W., Kahl, B. S., Spurgeon, S. E., Lannutti, B., Giese, N. A., Webb, H. K., Ulrich, R. G., Peterman, S. Holes, L. M., and Yu, A. S. (2010a). 
CAL-101, an isoform-selective inhibitor of phosphatidylinositol 3-Kinase P110 delta, demonstrates clinical activity and pharmacodynamic effects in patients with relapsed or refractory chronic lymphocytic leukemia. Blood 116, 31.

Furman, R. R., Byrd, J. C., Flinn, I. W., Coutre, S. E., Benson, J. D. M., Brown, J. R., Kahl, B. S., WagnerJohnston, N. D., Giese, N. A., and Yu, A. S. (2010b). Interim results from a phase I study of CAL-101, a selective oral inhibitor of phosphatidylinositol 3-kinase p110delta isoform, in patients with relapsed or refractory hematologic malignancies. J. Clin. Oncol. 28, Abstract 3032.

Garcia-Martinez, J. M., Wullschleger, S., Preston, G., Guichard, S., Fleming, S., Alessi, D. R., and Duce, S. L. (2011). Effect of PI3K- and mTOR-specific inhibitors on spontaneous B-cell follicular lymphomas in PTEN/LKB1-deficient mice. Br. J. Cancer 104, 1116-1125.

Gong, Q., Ou, Q., Ye, S., Lee, W. P., Cornelius, J., Diehl, L., Lin, W. Y., $\mathrm{Hu}, \mathrm{Z}$., Lu, Y., Chen, Y., Wu, Y., Meng, Y. G., Gribling, P., Lin, Z., Nguyen, K., Tran, T., Zhang, Y., Rosen, H., Martin, F., and Chan, A. C. (2005). Importance of cellular microenvironment and circulatory dynamics in B cell immunotherapy. J. Immunol. 174, 817-826.

Griffin, D. O., and Rothstein, T. L. (2011). A small CD11b(+) human B1 cell subpopulation stimulates $\mathrm{T}$ cells and is expanded in lupus. J. Exp. Med. 208, 2591-2598.

Ha, S. A., Tsuji, M., Suzuki, K., Meek, B., Yasuda, N., Kaisho, T., and Fagarasan, S. (2006). Regulation of B1 cell migration by signals through Toll-like receptors. J. Exp. Med. 203, 2541-2550.

Haxhinasto, S., Mathis, D., and Benoist, C. (2008). The AKT-mTOR axis regulates de novo differentiation of CD4+Foxp3+ cells. J. Exp. Med. 205, 565-574.

Haylock-Jacobs, S., Comerford, I., Bunting, M., Kara, E., Townley, S., Klingler-Hoffmann, M., Vanhaesebroeck, B., Puri, K. D., and McColl, S. R. (2011). PI3Kdelta drives the pathogenesis of experimental autoimmune encephalomyelitis by inhibiting effector $\mathrm{T}$ cell apoptosis and promoting Th17 differentiation. $J$. Autoimmun. 36, 278-287.

Hegedus, L., Smith, T. J., Douglas, R. S., and Nielsen, C. H. (2011). Targeted biological therapies for Graves' disease and thyroid-associated ophthalmopathy. Focus on B-cell depletion with Rituximab. Clin. Endocrinol. (Oxf.) 74, 1-8.

Henley, T., Kovesdi, D., and Turner, M. (2008). B-cell responses to B-cell activation factor of the TNF family (BAFF) are impaired in the absence of PI3K delta. Eur. J. Immunol. 38, 3543-3548.

Herishanu, Y., Perez-Galan, P., Liu, D., Biancotto, A., Pittaluga, S., Vire, B., Gibellini, F., Njuguna, N., Lee, E., Stennett, L., Raghavachari, N., Liu, P., McCoy, J. P., Raffeld, M., StetlerStevenson, M., Yuan, C., Sherry, R. Arthur, D. C., Maric, I., White, T., Marti, G. E., Munson, P., Wilson, W. H., and Wiestner, A. (2011). The lymph node microenvironment promotes B-cell receptor signaling, NF-kappaB activation, and tumor proliferation in chronic lymphocytic leukemia. Blood 117, 563-574.

Herman, S. E., Gordon, A. L., Wagner, A. J., Heerema, N. A., Zhao, W., Flynn, J. M., Jones, J., Andritsos, L., Puri, K. D., Lannutti, B. J., Giese, N. A., Zhang, X., Wei, L., Byrd, J. C., and Johnson, A. J. (2010). Phosphatidylinositol 3-kinase-delta inhibitor CAL-101 shows promising preclinical activity in chronic lymphocytic leukemia by antagonizing intrinsic and extrinsic cellular survival signals. Blood 116, 2078-2088.

Hirsch, E., Katanaev, V. L., Garlanda, C., Azzolino, O., Pirola, L., Silengo, L., Sozzani, S., Mantovani, A., Altruda, F., and Wymann, M. P. (2000). Central role for $\mathrm{G}$ proteincoupled phosphoinositide 3-kinase gamma in inflammation. Science 287, 1049-1053.

Hoellenriegel, J., Meadows, S. A., Sivina, M., Wierda, W. G. Kantarjian, H., Keating, M. J., Giese, N., O’brien, S., Yu, A., Miller L. L., Lannutti, B. J., and Burger, J. A. (2011). The phosphoinositide 3'-kinase delta inhibitor, CAL-101, inhibits B-cell receptor signaling and chemokine networks in chronic lymphocytic leukemia. Blood 118, 3603-3612.

Hu, C. Y., Rodriguez-Pinto, D., Du, W., Ahuja, A., Henegariu, O., Wong, F. S., Shlomchik, M. J., and Wen, L. (2007). Treatment with CD20specific antibody prevents and reverses autoimmune diabetes in mice. J. Clin. Invest. 117, 3857-3867.

Ikeda, H., Hideshima, T., Fulciniti, M., Perrone, G., Miura, N., Yasui, H., Okawa, Y., Kiziltepe, T., Santo, L., Vallet, S., Cristea, D., Calabrese, E., Gorgun, G., Raje, N. S., Richardson, P., Munshi, N. C., Lannutti, B. J., Puri, K. D., Giese, N. A., and Anderson, K. C. (2010).
PI3K/p1108 is a novel therapeutic target in multiple myeloma. Blood 116, 1460-1468.

Ishida, D., Su, L., Tamura, A. Katayama, Y., Kawai, Y., Wang, S. F., Taniwaki, M., Hamazaki, Y., Hattori, M., and Minato, N (2006). Rap1 signal controls B cell receptor repertoire and generation of self-reactive Bla cells. Immunity 24, 417-427.

Jain, R., Tartar, D. M., Gregg, R. K., Divekar, R. D., Bell, J. J., Lee, H H., Yu, P., Ellis, J. S., Hoeman, C. M., Franklin, C. L., and Zaghouani, H. (2008). Innocuous IFNgamma induced by adjuvant-free antigen restores normoglycemia in NOD mice through inhibition of IL17 production. J. Exp. Med. 205, 207-218.

Ji, H., Rintelen, F., Waltzinger, C., Bertschy Meier, D., Bilancio, A. Pearce, W., Hirsch, E., Wymann, M. P., Ruckle, T., Camps, M., Vanhaesebroeck, B., Okkenhaug, K., and Rommel, C. (2007). Inactivation of PI3Kgamma and PI3Kdelta distorts T-cell development and causes multiple organ inflammation. Blood 110 2940-2947.

Jou, S. T., Carpino, N., Takahashi, Y., Piekorz, R., Chao, J. R., Carpino, N., Wang, D., and Ihle, J. N. (2002). Essential, nonredundant role for the phosphoinositide 3-kinase p110delta in signaling by the B-cell receptor complex. Mol. Cell. Biol. $22,8580-8591$.

Jou, S. T., Chien, Y. H., Yang, Y. H., Wang, T. C., Shyur, S. D., Chou, C. C., Chang, M. L., Lin, D. T., Lin, K. H., and Chiang, B. L. (2006). Identification of variations in the human phosphoinositide 3 kinase p110delta gene in children with primary B-cell immunodeficiency of unknown aetiology. Int J. Immunogenet. 33, 361-369.

Kahl, B., Byrd, J., Flinn, I., WagnerJohnston, N., Spurgeon, S., Benson, D., Furman, R., Brown, J., Coutre, S., and Yu, A. (2011). Significant clinical activity of Cal-101, an isoform-selective inhibitor of phosphatidylinositol 3-kinase p110delta in patients with relapsed or refractory indolent and mantle vell lymphoma. Ann. Oncol. 22, 199.

Kahl, B., Byrd, J. C., Flinn, I. W., Wagner-Johnston, N., Spurgeon, S., Benson, D. M., Furman, R. R. Brown, J. R., Coutre, S., Lannutti, B., Giese, N. A., Ulrich, R. G., Webb, H. K., Peterman, S., Holes, L., and Yu, A. S. (2010). Clinical safety and activity in a phase 1 study of CAL-101, an isoform-selective inhibitor of phosphatidylinositol 3-kinase p110 delta, in patients with relapsed or refractory NonHodgkin lymphoma. Blood 116, 741.

Katz, J. D., Wang, B., Haskins, K. Benoist, C., and Mathis, D. (1993). Following a diabetogenic $\mathrm{T}$ cell from genesis through pathogenesis. Cell 74, 1089-1100.

Kazkaz, H., and Isenberg, D. (2004). Anti B cell therapy (rituximab) in the treatment of autoimmune diseases. Curr. Opin. Pharmacol. 4, 398-402.

Khare, S. D., Sarosi, I., Xia, X. Z., McCabe, S., Miner, K., Solovyev, I., Hawkins, N., Kelley, M., Chang, D., Van, G., Ross, L., Delaney, J., Wang, L., Lacey, D., Boyle, W. J., and Hsu, H. (2000). Severe B cell hyperplasia and autoimmune disease in TALL1 transgenic mice. Proc. Natl. Acad. Sci. U.S.A. 97, 3370-3375.

Kim, H. J., and Berek, C. (2000). B cells in rheumatoid arthritis. Arthritis Res. 2, 126-131.

Kim, N., Saudemont, A., Webb, L., Camps, M., Ruckle, T., Hirsch, E. Turner, M., and Colucci, F. (2007). The pl10delta catalytic isoform of PI3K is a key player in NK-cell development and cytokine secretion. Blood 110, 3202-3208.

Lannutti, B. J., Meadows, S. A. Herman, S. E., Kashishian, A., Steiner, B., Johnson, A. J., Byrd, J. C., Tyner, J. W., Loriaux, M. M., Deininger, M., Druker, B. J., Puri, K. D., Ulrich, R. G., and Giese, N. A. (2011). CAL-101, a p110delta selective phosphatidylinositol-3kinase inhibitor for the treatment of B-cell malignancies, inhibits PI3K signaling and cellular viability. Blood 117, 591-594.

Lebien, T. W., and Tedder, T. F (2008). B lymphocytes: how they develop and function. Blood 112, 1570-1580

Lee, K. S., Lee, H. K., Hayflick, J. S., Lee, Y. C., and Puri, K. D (2006). Inhibition of phosphoinositide 3-kinase delta attenuates allergic airway inflammation and hyperresponsiveness in murine asthma model. FASEB J. 20, 455-465.

Lemmon, M. A. (2008). Membrane recognition by phospholipidbinding domains. Nat. Rev. Mol. Cell Biol. 9, 99-111.

Leonard, J., Schreeder, M., Coutre, S., Flinn, I., Wagner-Johnston, N., Devos, S., Boccia, R., Holes, L. Peterman, S., Miller, L., and Yu, A. (2011). A phase 1 study of Cal101, an isoform-selective inhibitor of phosphatidylinositol 3-kinase pl10delta, in combination with 
anti-CD20 monoclonal antibody therapy and/or bendamustine in patients with previously treated B-cell malignancies. Ann. Oncol. 22, 137.

Lipsky, P. E. (2001). Systemic lupus erythematosus: an autoimmune disease of B cell hyperactivity. Nat. Immunol. 2, 764-766.

Luo, X., Herold, K. C., and Miller, S. D. (2010). Immunotherapy of type 1 diabetes: where are we and where should we be going? Immunity 32, 488-499.

Mackay, F., Woodcock, S. A., Lawton, P., Ambrose, C., Baetscher, M., Schneider, P., Tschopp, J., and Browning, J. L. (1999). Mice transgenic for BAFF develop lymphocytic disorders along with autoimmune manifestations. J. Exp. Med. 190, 1697-1710.

Marino, E., Batten, M., Groom, J., Walters, S., Liuwantara, D., Mackay, F., and Grey, S. T. (2008). Marginalzone B-cells of nonobese diabetic mice expand with diabetes onset, invade the pancreatic lymph nodes, and present autoantigen to diabetogenic T-cells. Diabetes 57, 395-404.

Marino, E., and Grey, S. T. (2008). A new role for an old player: do $B$ cells unleash the self-reactive CD8+ $\mathrm{T}$ cell storm necessary for the development of type 1 diabetes? J. Autoimmun. 31, 301-305.

Martin, F., and Chan, A. C. (2006). B cell immunobiology in disease: evolving concepts from the clinic. Аnпu. Rev. Immunol. 24, 467-496.

Martinez, N., Camacho, F. I., Algara, P., Rodriguez, A., Dopazo, A., RuizBallesteros, E., Martin, P., MartinezCliment, J. A., Garcia-Conde, J., Menarguez, J., Solano, F., Mollejo, M., and Piris, M. A. (2003). The molecular signature of mantle cell lymphoma reveals multiple signals favoring cell survival. Cancer Res. 63, 8226-8232.

Matsushita, T., Yanaba, K., Bouaziz, J. D., Fujimoto, M., and Tedder, T. F. (2008). Regulatory B cells inhibit EAE initiation in mice while other $B$ cells promote disease progression. J. Clin. Invest. 118, 3420-3430.

Maxwell, M. J., Tsantikos, E., Kong, A. M., Vanhaesebroeck, B., Tarlinton, D. M., and Hibbs, M. L. (2012). Attenuation of phosphoinositide 3-kinase delta signaling restrains autoimmune disease. J. Autoimmun. $38,381-391$

Meadows, S. A., Vega, F., Kashishian, A., Johnson, D., Diehl, V., Miller, L. L., Younes, A., and Lannutti, B. J. (2012). PI3Kdelta inhibitor, GS-1101 (CAL-101), attenuates pathway signaling, induces apoptosis, and overcomes signals from the microenvironment in cellular models of Hodgkin lymphoma. Blood 119, 1897-1900.

Mizoguchi, A., and Bhan, A. K. (2006). A case for regulatory B cells. J. Immunol. 176, 705-710.

Montecino-Rodriguez, E., Leathers, H., and Dorshkind, K. (2006). Identification of a B-1 B cellspecified progenitor. Nat. Immunol. 7, 293-301.

Murakami, M., and Honjo, T. (1997). Transgenic mouse models for Bcell dominant autoimmune diseases. Curr. Opin. Immunol. 9, 846-850.

Murakami, M., Yoshioka, H., Shirai, T., Tsubata, T., and Honjo, T. (1995). Prevention of autoimmune symptoms in autoimmune-prone mice by elimination of B-1 cells. Int. Immunol. 7, 877-882.

Noorchashm, H., Lieu, Y. K., Noorchashm, N., Rostami, S. Y., Greeley, S. A., Schlachterman, A., Song, H. K., Noto, L. E., Jevnikar, A. M., Barker, C. F., and Naji, A. (1999a). I-Ag7-mediated antigen presentation by $\mathrm{B}$ lymphocytes is critical in overcoming a checkpoint in $\mathrm{T}$ cell tolerance to islet beta cells of nonobese diabetic mice. J. Immunol. 163, 743-750.

Noorchashm, H., Moore, D. J., Lieu, Y. K., Noorchashm, N., Schlachterman, A., Song, H. K., Barker, C. F., and Naji, A. (1999b). Contribution of the innate immune system to autoimmune diabetes: a role for the CR1/CR2 complement receptors. Cell. Immunol. 195, 75-79.

Noorchashm, H., Noorchashm, N., Kern, J., Rostami, S. Y., Barker, C. F., and Naji, A. (1997). B-cells are required for the initiation of insulitis and sialitis in nonobese diabetic mice. Diabetes 46, 941-946.

Norman, P. (2011). Selective PI3Kdelta inhibitors, a review of the patent literature. Expert Opin. Ther. Pat. 21, 1773-1790.

Ochsenbein, A. F., Fehr, T., Lutz, C., Suter, M., Brombacher, F., Hengartner, H., and Zinkernagel, R. M. (1999). Control of early viral and bacterial distribution and disease by natural antibodies. Science 286, 2156-2159.

Okkenhaug, K., Bilancio, A., Farjot, G., Priddle, H., Sancho, S., Peskett, E., Pearce, W., Meek, S. E., Salpekar, A., Waterfield, M. D., Smith, A. J., and Vanhaesebroeck, B. (2002). Impaired $\mathrm{B}$ and $\mathrm{T}$ cell antigen receptor signaling in p110delta PI 3kinase mutant mice. Science 297, 1031-1034.
Okkenhaug, K., and Fruman, D. A. (2010). PI3Ks in lymphocyte signaling and development. Curr. Top. Microbiol. Immunol. 346, 57-85.

Okkenhaug, K., Patton, D. T., Bilancio, A., Garcon, F., Rowan, W. C., and Vanhaesebroeck, B. (2006). The p110delta isoform of phosphoinositide 3-kinase controls clonal expansion and differentiation of Th cells. J. Immunol. 177, 5122-5128.

Okkenhaug, K., and Vanhaesebroeck, B. (2003). PI3K in lymphocyte development, differentiation and activation. Nat. Rev. Immunol. 3 , 317-330.

Oliver, A. M., Martin, F., and Kearney, J. F. (1999). IgMhighCD21 high lymphocytes enriched in the splenic marginal zone generate effector cells more rapidly than the bulk of follicular B cells. J. Immunol. 162, 7198-7207.

Pao, L. I., Lam, K. P., Henderson, J. M., Kutok, J. L., Alimzhanov, M., Nitschke, L., Thomas, M. L., Neel, B. G., and Rajewsky, K. (2007). B cellspecific deletion of protein-tyrosine phosphatase Shpl promotes B-1a cell development and causes systemic autoimmunity. Immunity 27 , 35-48.

Park, S. J., Lee, K. S., Kim, S. R., Min, K. H., Moon, H., Lee, M. H., Chung, C. R., Han, H. J., Puri, K. D., and Lee, Y. C. (2010). Phosphoinositide 3-kinase delta inhibitor suppresses interleukin-17 expression in a murine asthma model. Eur. Respir. J. 36, 1448-1459.

Patton, D. T., Garden, O. A., Pearce, W. P., Clough, L. E., Monk, C. R., Leung, E., Rowan, W. C., Sancho, S., Walker, L. S., Vanhaesebroeck, B. and Okkenhaug, K. (2006). Cutting edge: the phosphoinositide 3-kinase p110 delta is critical for the function of CD4+CD25+Foxp3+ regulatory T cells. J. Immunol. 177, 6598-6602. Pescovitz, M. D., Greenbaum, C. J., Krause-Steinrauf, H., Becker, D. J., Gitelman, S. E., Goland, R., Gottlieb, P. A., Marks, J. B., McGee, P. F., Moran, A. M., Raskin, P., Rodriguez, H., Schatz, D. A., Wherrett, D., Wilson, D. M., Lachin, J. M., and Skyler, J. S. (2009). Rituximab, B-lymphocyte depletion, and preservation of beta-cell function. N. Engl. J. Med. 361, 2143-2152.

Pighi, C., Gu, T. L., Dalai, I., Barbi, S., Parolini, C., Bertolaso, A., Pedron, S., Parisi, A., Ren, J., Cecconi, D., Chilosi, M., Menestrina, F., and Zamo, A. (2011). Phosphoproteomic analysis of mantle cell lymphoma cells suggests a prosurvival role of B-cell receptor signaling. Cell. Oncol. (Dordr.) 34, 141-153.

Pillai, S., and Cariappa, A. (2009). The follicular versus marginal zone B lymphocyte cell fate decision. Nat. Rev. Immunol. 9, 767-777.

Pillai, S., Cariappa, A., and Moran, S. T. (2005). Marginal zone B cells. Annu. Rev. Immunol. 23, 161-196.

Puri, K. D., Doggett, T. A., Douangpanya, J., Hou, Y., Tino, W. T., Wilson, T., Graf, T., Clayton, E., Turner, M., Hayflick, J. S., and Diacovo, T. G. (2004). Mechanisms and implications of phosphoinositide 3-kinase delta in promoting neutrophil trafficking into inflamed tissue. Blood 103, 3448-3456.

Putz, E. M., Prchal-Murphy, M., Simma, O. A., Forster, F., Koenig, X., Stockinger, H., Piekorz, R. P., Freissmuth, M., Muller, M., Sexl, V., and Zebedin-Brandl, E. (2012). PI3Kdelta is essential for tumor clearance mediated by cytotoxic $\mathrm{T}$ lymphocytes. PLOS ONE 7:e40852. doi: 10.1371/journal.pone.0040852

Ramadani, F., Bolland, D. J., Garcon, F., Emery, J. L., Vanhaesebroeck, B., Corcoran, A. E., and Okkenhaug, K. (2010). The PI3K isoforms p110alpha and p110delta are essential for pre-B cell receptor signaling and B cell development. Sci. Signal. 3 , ra60.

Randis, T. M., Puri, K. D., Zhou, H., and Diacovo, T. G. (2008). Role of PI3Kdelta and PI3Kgamma in inflammatory arthritis and tissue localization of neutrophils. Eur. J. Immunol. 38, 1215-1224.

Reif, K., Okkenhaug, K., Sasaki, T., Penninger, J. M., Vanhaesebroeck, B., and Cyster, J. G. (2004). Cutting edge: differential roles for phosphoinositide 3-kinases, p110gamma and p110delta, in lymphocyte chemotaxis and homing. J. Immunol. 173, 2236-2240.

Renne, C., Willenbrock, K., MartinSubero, J. I., Hinsch, N., Doring, C., Tiacci, E., Klapper, W., Moller, P., Kuppers, R., Hansmann, M. L., Siebert, R., and Brauninger, A. (2007). High expression of several tyrosine kinases and activation of the PI3K/AKT pathway in mediastinal large B cell lymphoma reveals further similarities to Hodgkin lymphoma. Leukemia 21, 780-787.

Rinaldi, A., Kwee, I., Taborelli, M., Largo, C., Uccella, S., Martin, V., Poretti, G., Gaidano, G., Calabrese, G., Martinelli, G., Baldini, L., Pruneri, G., Capella, C., Zucca, E., Cotter, F. E., Cigudosa, J. C., Catapano, C. V., Tibiletti, 
M. G., and Bertoni, F. (2006). Genomic and expression profiling identifies the B-cell associated tyrosine kinase Syk as a possible therapeutic target in mantle cell lymphoma. Br. J. Haematol. 132, 303-316.

Rizzatti, E. G., Falcao, R. P., Panepucci, R. A., Proto-Siqueira, R., AnselmoLima, W. T., Okamoto, O. K., and Zago, M. A. (2005). Gene expression profiling of mantle cell lymphoma cells reveals aberrant expression of genes from the PI3K-AKT, WNT and TGFbeta signalling pathways. Br. J. Haematol. 130, 516-526.

Rolf, J., Motta, V., Duarte, N., Lundholm, M., Berntman, E., Bergman, M. L., Sorokin, L., Cardell, S. L., and Holmberg, D. (2005). The enlarged population of marginal zone/CD1d(high) B lymphocytes in nonobese diabetic mice maps to diabetes susceptibility region Idd11. J. Immunol. 174, 4821-4827.

Rommel, C., Camps, M., and Ji, H. (2007). PI3K delta and PI3K gamma: partners in crime in inflammation in rheumatoid arthritis and beyond? Nat. Rev. Immunol. 7, 191-201.

Rubtsov, A. V., Swanson, C. L., Troy, S., Strauch, P., Pelanda, R., and Torres, R. M. (2008). TLR agonists promote marginal zone B cell activation and facilitate $\mathrm{T}$-dependent IgM responses. J. Immunol. 180, 3882-3888.

Rudelius, M., Pittaluga, S., Nishizuka, S., Pham, T. H., Fend, F., Jaffe, E. S., Quintanilla-Martinez, L., and Raffeld, M. (2006). Constitutive activation of Akt contributes to the pathogenesis and survival of mantle cell lymphoma. Blood 108, 1668-1676.

Ryan, G. A., Wang, C. J., Chamberlain, J. L., Attridge, K., Schmidt, E. M., Kenefeck, R., Clough, L. E., Dunussi-Joannopoulos, K., Toellner, K. M., and Walker, L. S. (2010). B1 cells promote pancreas infiltration by autoreactive $\mathrm{T}$ cells. J. Immunol. 185, 2800-2807.

Sadhu, C., Dick, K., Tino, W. T., and Staunton, D. E. (2003a). Selective role of PI3K delta in neutrophil inflammatory responses. Biochem. Biophys. Res. Commun. 308, 764-769.

Sadhu, C., Masinovsky, B., Dick, K., Sowell, C. G., and Staunton, D. E. (2003b). Essential role of phosphoinositide 3-kinase delta in neutrophil directional movement. J. Immunol. 170, 2647-2654.

Sanz, I., Anolik, J. H., and Looney, R. J. (2007). B cell depletion therapy in autoimmune diseases. Front. Biosci. 12, 2546-2567.

Sasaki, T., Irie-Sasaki, J., Jones, R. G., Oliveira-Dos-Santos, A. J., Stanford, W. L., Bolon, B., Wakeham, A., Itie, A., Bouchard, D., Kozieradzki, I., Joza, N., Mak, T. W., Ohashi, P. S., Suzuki, A., and Penninger, J. M. (2000). Function of PI3Kgamma in thymocyte development, T cell activation, and neutrophil migration. Science 287, 1040-1046.

Saudemont, A., Okkenhaug, K., and Colucci, F. (2007). p110delta is required for innate immunity to transplantable lymphomas. Biochem. Soc. Trans. 35, 183-185.

Sauer, S., Bruno, L., Hertweck, A., Finlay, D., Leleu, M., Spivakov, M., Knight, Z. A., Cobb, B. S., Cantrell, D., O'connor, E., Shokat, K. M., Fisher, A. G., and Merkenschlager, M. (2008). T cell receptor signaling controls Foxp3 expression via PI3K, Akt, and mTOR. Proc. Natl. Acad. Sci. U.S.A. 105, 7797-7802.

Schmid, M. C., Avraamides, C. J., Dippold, H. C., Franco, I., Foubert, P., Ellies, L. G., Acevedo, L. M., Manglicmot, J. R., Song, X., Wrasidlo, W., Blair, S. L., Ginsberg, M. H., Cheresh, D. A., Hirsch, E., Field, S. J., and Varner, J. A. (2011). Receptor tyrosine kinases and TLR/IL1Rs unexpectedly activate myeloid cell PI3kgamma, a single convergent point promoting tumor inflammation and progression. Cancer Cell 19, 715-727.

Serreze, D. V., Chapman, H. D., Varnum, D. S., Hanson, M. S., Reifsnyder, P. C., Richard, S. D., Fleming, S. A., Leiter, E. H., and Shultz, L. D. (1996). B lymphocytes are essential for the initiation of $\mathrm{T}$ cell-mediated autoimmune diabetes: analysis of a new "speed congenic" stock of NOD.Ig mu null mice. J. Exp. Med. 184, 2049-2053.

Sharman, J., De Vos, S., Leonard, J. P., Furman, R. R., Coutre, S. E., Flinn, I. W., Schreeder, M. T., Barrientos, J. C., Wagner-Johnston, N. D., Boyd, T., Fowler, N. H., Holes, L., Lannutti, B., Johnson, D., Jahn, T. M., and Miller, L. L. (2011). A phase 1 study of the selective phosphatidylinositol 3-kinasedelta (PI3K delta) inhibitor, CAL101 (GS-1101), in combination with rituximab and/or bendamustine in patients with relapsed or refractory chronic lymphocytic leukemia (CLL). Blood 118, 779-780.

Shlomchik, M. J. (2008). Sites and stages of autoreactive B cell activation and regulation. Immunity $28,18-28$.
Sinclair, L. V., Finlay, D., Feijoo, C., Cornish, G. H., Gray, A., Ager A., Okkenhaug, K., Hagenbeek, T. J., Spits, H., and Cantrell, D. A. (2008). Phosphatidylinositol-3$\mathrm{OH}$ kinase and nutrient-sensing mTOR pathways control T lymphocyte trafficking. Nat. Immunol. 9, 513-521.

So, L., and Fruman, D. A. (2012). PI3K signalling in B- and T-lymphocytes: new developments and therapeutic advances. Biochem. J. 442, 465-481.

Soond, D. R., Bjorgo, E., Moltu, K., Dale, V. Q., Patton, D. T., Torgersen, K. M., Galleway, F., Twomey, B. Clark, J., Gaston, J. S., Tasken, K., Bunyard, P., and Okkenhaug, $\mathrm{K}$. (2010). PI3K p110delta regulates T-cell cytokine production during primary and secondary immune responses in mice and humans. Blood 115, 2203-2213.

Srinivasan, L., Sasaki, Y., Calado, D. P., Zhang, B., Paik, J. H., Depinho, R. A., Kutok, J. L., Kearney, J. F., Otipoby, K. L., and Rajewsky, K. (2009). PI3 kinase signals BCRdependent mature B cell survival. Cell 139, 573-586.

Stein, J. V., and Nombela-Arrieta, C. (2005). Chemokine control of lymphocyte trafficking: a general overview. Immunology 116, 1-12.

Suarez-Fueyo, A., Barber, D. F. Martinez-Ara, J., Zea-Mendoza, A. C., and Carrera, A. C. (2011). Enhanced phosphoinositide 3kinase delta activity is a frequent event in systemic lupus erythematosus that confers resistance to activation-induced $\mathrm{T}$ cell death J. Immunol. 187, 2376-2385.

Suzuki, H., Terauchi, Y., Fujiwara, M. Aizawa, S., Yazaki, Y., Kadowaki, T., and Koyasu, S. (1999). Xid-like immunodeficiency in mice with disruption of the p85alpha subunit of phosphoinositide 3-kinase. Science 283, 390-392.

Takemura, S., Braun, A., Crowson, C. Kurtin, P. J., Cofield, R. H., O'fallon, W. M., Goronzy, J. J., and Weyand, C. M. (2001). Lymphoid neogenesis in rheumatoid synovitis. $J$. Immunol. 167, 1072-1080.

Tian, J., Zekzer, D., Lu, Y., Dang, H., and Kaufman, D. L. (2006). B cells are crucial for determinant spreading of $\mathrm{T}$ cell autoimmunity among beta cell antigens in diabetes-prone nonobese diabetic mice. J. Immunol. 176, 2654-2661.

Uddin, S., Hussain, A. R., Siraj, A. K. Manogaran, P. S., Al-Jomah, N. A., Moorii, A., Atizado, V., Al-Dayel, F., Belgaumi, A., El-Solh, H., Ezzat, A., Bavi, P., and Al-Kuraya, K. S.
(2006). Role of phosphatidylinositol $3^{\prime}$-kinase/AKT pathway in diffuse large B-cell lymphoma survival. Blood 108, 4178-4186.

Vanhaesebroeck, B., GuillermetGuibert, J., Graupera, M., and Bilanges, B. (2010). The emerging mechanisms of isoform-specific PI3K signalling. Nat. Rev. Mol. Cell Biol. 11, 329-341.

Viau, M., and Zouali, M. (2005). Effect of the B cell superantigen protein A from $S$. aureus on the early lupus disease of (NZBxNZW) F1 mice. Mol. Immunol. 42, 849-855.

Vogel, W. H. (2010). Infusion reactions: diagnosis, assessment, and management. Clin. J. Oncol. Nurs. 14, E10-E21.

Weber, M. S., Prod'homme, T., Patarroyo, J. C., Molnarfi, N., Karnezis, T., Lehmann-Horn, K., Danilenko, D. M., EasthamAnderson, J., Slavin, A. J., Linington, C., Bernard, C. C., Martin, F., and Zamvil, S. S. (2010). B-cell activation influences $\mathrm{T}$-cell polarization and outcome of anti-CD20 B-cell depletion in central nervous system autoimmunity. Ann. Neurol. 68, 369-383.

Weill, J. C., Weller, S., and Reynaud, C. A. (2009). Human marginal zone B cells. Annu. Rev. Immunol. 27, 267-285.

Williams, O., Houseman, B. T., Kunkel, E. J., Aizenstein, B., Hoffman, R., Knight, Z. A., and Shokat, K. M. (2010). Discovery of dual inhibitors of the immune cell PI3Ks p110delta and p110gamma: a prototype for new anti-inflammatory drugs. Chem. Biol. 17, 123-134.

Wither, J. E., Roy, V., and Brennan, L. A. (2000). Activated B cells express increased levels of costimulatory molecules in young autoimmune NZB and (NZB x NZW)F(1) mice. Clin. Immunol. 94, 51-63.

Wong, F. S., Wen, L., Tang, M., Ramanathan, M., Visintin, I., Daugherty, J., Hannum, L. G., Janeway, C. A. Jr., and Shlomchik, M. J. (2004). Investigation of the role of B-cells in type 1 diabetes in the NOD mouse. Diabetes 53, 2581-2587.

Xiu, Y., Wong, C. P., Bouaziz, J. D., Hamaguchi, Y., Wang, Y., Pop, S. M., Tisch, R. M., and Tedder, T. F. (2008). B lymphocyte depletion by CD20 monoclonal antibody prevents diabetes in nonobese diabetic mice despite isotype-specific differences in Fc gamma R effector functions. J. Immunol. 180, 2863-2875.

Yanaba, K., Bouaziz, J. D., Matsushita, T., Magro, C. M., St Clair, E. W., and Tedder, T. F. (2008). B-lymphocyte 
contributions to human autoimmune disease. Immunol. Rev. 223, 284-299.

Yu, S., Dunn, R., Kehry, M. R., and Braley-Mullen, H. (2008). B cell depletion inhibits spontaneous autoimmune thyroiditis in NOD.H-2h4 mice. J. Immunol. 180, 7706-7713.

Zekavat, G., Rostami, S. Y., Badkerhanian, A., Parsons, R. F., Koeberlein, B., Yu, M., Ward, C. D., Migone, T. S., Yu, L., Eisenbarth, G. S., Cancro, M. P., Naji, A., and Noorchashm, H. (2008). In vivo BLyS/BAFF neutralization ameliorates isletdirected autoimmunity in nonobese diabetic mice. J. Immunol. 181, 8133-8144.
Zent, C. S., Laplant, B. R., Johnston, P. B., Call, T. G., Habermann, T. M., Micallef, I. N., and Witzig, T. E. (2010). The treatment of recurrent/refractory chronic lymphocytic leukemia/small lymphocytic lymphoma (CLL) with everolimus results in clinical responses and mobilization of CLL cells into the circulation. Cancer 116, 2201-2207.

Zhang, M., and Carroll, M. C. (2007). Natural antibody mediated innate autoimmune response. Mol. Immunol. 44, 103-110.

Zhang, T. T., Makondo, K. J., and Marshall, A. J. (2012). p110delta phosphoinositide 3-kinase represses IgE switch by potentiating BCL6 expression. J. Immunol. 188, 3700-3708.
Zhang, T. T., Okkenhaug, K., Nashed, B. F., Puri, K. D., Knight, Z. A., Shokat, K. M., Vanhaesebroeck, B., and Marshall, A. J. (2008). Genetic or pharmaceutical blockade of p110delta phosphoinositide 3-kinase enhances IgE production. J. Allergy Clin. Immunol. 122, 811-819.

Conflict of Interest Statement: Kamal D. Puri is an employee of Gilead Sciences Inc., the manufacturer of IC87114 and GS-1101. Michael R. Gold has no commercial or financial relationships that could be construed as a potential conflict of interest.

Received: 06 June 2012; accepted: 31 July 2012; published online: 23 August 2012.
Citation: Puri KD and Gold MR (2012) Selective inhibitors of phosphoinositide 3-kinase delta: modulators of B-cell function with potential for treating autoimmune inflammatory diseases and B-cell malignancies. Front. Immun. 3:256. doi: 10.3389/fimmu.2012.00256

This article was submitted to Frontiers in B Cell Biology, a specialty of Frontiers in Immunology.

Copyright (c) 2012 Puri and Gold. This is an open-access article distributed under the terms of the Creative Commons Attribution License, which permits use, distribution and reproduction in other forums, provided the original authors and source are credited and subject to any copyright notices concerning any third-party graphics etc. 